\title{
DIGITALCOMMONS
}

@WAYNESTATE-

Wayne State University

Law Faculty Research Publications

Law School

$1-1-2004$

\section{Retrieving Marx for the Human Rights Project}

Brad R. Roth

Wayne State University

\section{Recommended Citation}

Roth, Brad R.. Retrieving Marx for the Human Rights Project. 17 LJIL 31, 66 (2004)

Available at: https://digitalcommons.wayne.edu/lawfrp/278

This Article is brought to you for free and open access by the Law School at DigitalCommons@WayneState. It has been accepted for inclusion in Law Faculty Research Publications by an authorized administrator of DigitalCommons@WayneState. 


\title{
Retrieving Marx for the Human Rights Project
}

\author{
BRAD R. ROTH*
}

\begin{abstract}
Marxian thought retains its relevance in the current period, not as a comprehensive replacement for liberal human rights theories, but as a source of critique that challenges those theories on the basis of the very values of human freedom and dignity that they espouse. The Marxian approach entails no general rejection of human-rights-oriented constraint, procedural or substantive, on efforts to achieve social change, but rather serves the human rights project by demonstrating how contradictory class interests manifest themselves as contradictions within the effort to apply liberal principles in a class-divided society.
\end{abstract}

\section{Key words}

human rights; liberalism; Marx; Marxism; socialism

Across the globe for well over a century, the ideas of Karl Marx held a special fascination for movements seeking to transform economic, political, and social conditions in favour of the 'have-nots'. That this fascination endured a spectacular array of disappointments, defeats, and disasters-ranging from the failure of Marxian predictions about the historical trajectory of capitalism to the massive commission of ignominious crimes in the name of Marxism - merely testifies to the power of those ideas to capture and hold the imagination of those who have yearned to transform the conditions of the disempowered and the deprived.

There are signs, however, that Marxism's hold on the activist imagination may now be at an end. Many of the movements that it has inspired have passed from the scene altogether; others are so fully in retreat that once-envisaged social transformations are no longer directly relevant to their political programmes; still others have adapted Marxian analytical and rhetorical devices to projects far removed from, and even at odds with, the struggle of a unified working class to wrest control of the means of production. To be sure, Marx's work has continued influence in a range of academic disciplines. Even so, its status has typically been downgraded from a comprehensive approach to scholarly inquiry to a discrete, if indispensable, step in the development of more eclectic approaches ${ }^{I}-$ the latter status befitting

\footnotetext{
Associate Professor of Political Science and Law, Wayne State University; JD, Harvard Law School, I987; LLM, Columbia Law School, I992; Ph.D., University of California, Berkeley, I996. This paper was presented at the symposium 'Marxism and International Law', organized by the Leiden Joumal of International Law in The Hague on I2-I3 Sept. 2003. I should like to thank the participants in this symposium and additionally Andreas Paulus, Thompson Bradley, and James Chalmers for their provocative comments.

I. See, e.g., T. B. Bottomore and M. Rubel, Karl Marx, Selected Writings in Sociology and Social Philosophy (I964), 48 ('A great deal of Marx's work is a permanent acquisition of sociological thought, [but] the incorporation
} 
a sweeping, interdisciplinary design that has had over a century for its flaws to be exposed. Analogously, if Marxian thought is to have twenty-first century relevance in the political and juridical realms, it will almost certainly not be in the form of a comprehensive set of analytical and normative principles, but as a continued source of insight and inspiration within more eclectic theoretical systems. ${ }^{2}$

Even this more limited role for Marx in the struggle for social change, however, is open to challenge. Marxian ideas, some suggest, are either detrimental or superfluous to the cause of the dispossessed, or at least to the most prominent contemporary modes of furthering that cause. The question thus arises for scholars and practitioners of international law: can Marxian political thought make a positive contribution to the contemporary project of international human rights advocacy?

Any effort to answer this question in the affirmative must confront three basic objections that sceptics have posed: first, that Marxism disdains to address the normative concerns that animate this project, regarding them as a 'utopian' distraction; second, that insofar as Marxism bears on the project at all, it is incompatible with (and perhaps even hostile to) the project; and third, that even if Marxism both bears upon and can be reconciled with the project, it is superfluous to it, adding nothing of substance to the contributions of the main current of contemporary liberal thought. None of these objections lacks foundation, but all neglect important sources of Marxian insight.

The discussion below will argue that the Marxian intellectual tradition, while not by itself an adequate guide to activism for social change, remains relevant and valuable to the furtherance of international human rights. It asserts that a humanrights-friendly reading of Marx is both available and edifying.

The corpus of Marx's work is sufficiently large and intricate that serious Marx scholars can arrive at completely contradictory accounts of its central themes, especially the pivotal relationship between the economic 'base' and the legal, political, social, and cultural 'superstructure'. This article will, where possible, avoid becoming enmeshed in the (sometimes extravagantly) extensive debates over which accounts are more 'authentic', other than to point out that there are certain views, sometimes associated with Marx, that Marx could not coherently have held, and other such views that are so thoroughly untenable that we should avoid attributing them to Marx if any plausible reading permits.

In arguing for Marxism's compatibility with the 'project of international human rights advocacy', the discussion below presupposes a non-dogmatic approach to the latter. Marx's work clearly cannot be reconciled with a 'natural rights' approach that attributes to rights a metaphysical existence that transcends human institutions, nor can Marx be interpreted to embrace the view that 'moral rights' are a distinctively useful construct in reasoning about political morality. The same can be said, however, about any number of thinkers, including John Stuart Mill, ${ }^{3}$ whose

of Marx's ideas entails the disappearance of "Marxist" sociology. Modern sociology ... is a science which has advanced some way towards freeing itself from the various philosophic systems in which it originated').

2. I use the word 'eclectic' deliberately, as it was frequently employed as a pejorative (akin to 'revisionist') in communist polemics.

3. J. S. Mill, 'On Liberty', in 'Utilitarianism', 'On Liberty', and 'Considerations on Representative Government' (I972), 65 at 74. ('I forego any advantage which could be derived to my argument from the idea of abstract right, as 
contributions to the human rights project are beyond cavil. Human rights advocates are united by the belief that certain legal norms pertaining to basic conditions of human flourishing ought, on the basis of moral considerations, to be promulgated and implemented globally; they are not united by any one particular elaboration be it theological, deontological, utilitarian, or perfectionist - of those moral considerations. The question at hand is whether Marxian thought can furnish intellectual resources for the political struggle to establish legal norms conducive to human flourishing, not whether Marx qualifies as a 'rights theorist'.

Nonetheless, the contention that Marxian thought can furnish such resources must confront the following objections. First, Marxism, as 'scientific' rather than 'utopian' socialism, supposedly repudiates normative theorizing as such, dismissing moralistic exhortation as irrelevant to the real, 'material' forces of history. Second, Marxism seeks to demonstrate the 'ideological' (and thus obfuscatory) character of rights claims and the impossibility of a justice that transcends class interests; not only does the characteristic Marxian 'debunking' of rights, justice, and the rule of law preclude a rights-oriented critique of capitalism, the argument goes, but it further precludes any rights-oriented constraint on the envisaged instrument for achievement of the imperative social transformation, the 'dictatorship of the proletariat'. Third, not only do Marx's prescriptions lack an explicit rights component, but his motivating vision of genuinely self-directed human activity (for which endstage communist society is expected to furnish the material basis), while congenial, neither contradicts nor even, it is argued, usefully complements the conception of human flourishing that contemporary liberalism aims to effect.

All of these objections, although containing a ring of truth, are incomplete and misleading. A retrieval of Marxian thought from the dustbin of activist history - and a retrieval of the human rights project from the conservatizing grip of conventional doctrine-call for a response to each.

\section{MARXISM AND THE NORMATIVE PROJECT}

The threshold objection that Marx does not meaningfully contribute to normative discourse proceeds from the unexceptionable premise that Marx, as a 'scientific' rather than 'utopian' socialist, regarded normative ideas as relevant only in a historical context that supplies the material preconditions to those ideas' realization. G. A. Cohen regretfully concludes on this basis that, in the absence of a historical context conforming to Marx's expectation, Marx's normative ideas are too thin to have application: they are relevant only to a particular choice at a materially conditioned historical moment, a moment that is not, and will never be, upon us. ${ }^{4}$

The great corpus of Marx's economic studies - building from a labour theory of value through an analysis of capital accumulation to establish the long-term inevitability of a falling rate of profit - served for Marx to substantiate the following proposition: the dynamics of capitalism will culminate in a crisis that will render

a thing independent of utility. I regard utility as the ultimate appeal on all ethical questions; but it must be utility in the largest sense, grounded on the permanent interests of man as a progressive being.)

4. See G. A. Cohen, If You're an Egalitarian, How Come You're So Rich? (2000). 
its contradictions both apparent to and unbearable for an overwhelming majority of the population..$^{5}$ Marx imputed to capitalism a structural tendency to unite the interests of those who lack command of productive resources. Their productive labour is the source of all wealth, and yet the processes of production extract from them much of the value of their labour, leaving them impoverished. At the same time, they manifestly possess the capacity to reorganize production in favour of their own interests, which form a cohesive set. ${ }^{6}$

As Cohen quite convincingly points out, the history of economic development has, in reality, de-linked the interests of those not owning the means of production: the productive and the impoverished are now largely discrete groups, both domestically and, above all, internationally. If the conditions for revolution will not naturally fall into place, it falls to socialists to construct a normative argument to establish the desirability of a socialist alternative to the existing order. ${ }^{7}$

In Cohen's view, the Marxian canon fails to supply a foundation for the needed normative theorizing. He describes Marx's scientific socialism as 'obstetric': 'the specific task allocated by Marx to socialist politics ... is that of "shortening and lessening the birth pangs" of the arrival of the new society'. ${ }^{8}$ The power of the obstetric metaphor leads Cohen to attribute to Marx the notion that 'the baby is what the baby is, not what the midwife designs it to be': socialism, once helped forth from the capitalist womb, will develop along a genetically determined path that the midwife does not affect.

Scientific socialism thus, for Cohen, entails 'a criminal inattention to what one is trying to achieve, to the problem of socialist design'. ${ }^{9}$ As evidence of this criminal inattention, he quotes one of Marxism's greatest intellectual and historical figures, Rosa Luxemburg:

when it comes to the nature of the thousand concrete, practical measures, large and small, necessary to introduce socialist principles into economy, law, and all social relationships, there is no key in any socialist party program or textbook. This is not a shortcoming but rather the very thing that makes scientific socialism superior to the utopian varieties. ${ }^{\text {IO }}$

Cohen's argument neglects the crucial distinction between the normative and the utopian. Normative political thought generates (or at least helps to generate) standards for political behaviour in concrete circumstances. Utopian political thought, on the other hand, visualizes a state of affairs, corresponding to the realization of its ideal project, for whose bringing into being it can supply no realistic strategy. It is

5. It is by now widely recognized that, while aspects of Marx's framework may yet yield important insights about the operation of the capitalist economy, the conclusions that would have established the inevitability of capitalism's collapse cannot be sustained. The analysis founders on the impossibility of substantiating the claim of a long-term relationship between the prices of goods and the labour-time embodied in their production, the so-called 'transformation problem'. See I. Steedman, Marx after Sraffa (I98I).

6. Cohen, supra note 4 , at 107.

7. Ibid., at II 2-I5; see also W. Kymlicka, Liberalism, Community, and Culture (I989), II 2 (making the same observation).

8. Cohen, supra note 4, at 76, quoting K. Marx, Capital, Vol. I, trans. B. Fowkes (I976), 92.

9. Cohen, supra note 4 , at 77 .

Io. R. Luxemburg, 'The Russian Revolution', in 'The Russian Revolution' and 'Leninism or Marxism?' (1970), 70, quoted in Cohen, supra note 4 , at I96, n. 47. 
incapable of generating real standards for political behaviour, because all standards appropriate to its project are, as an essential characteristic, subject to material conditions that are both precedent and unlikely to be fulfilled in the foreseeable term. At the same time, because utopian thought is not bounded by the real conditions and contingencies that limit the effectiveness of well-intentioned policies, it is free to specify detailed policies and to impute to them the desired effects, whereas normative thought can generate only the criteria by which the actual and scientifically projected effects of a given policy can be evaluated.

That Marx dismissed utopian political thought as an ultimately inconsequential exercise is no indication that he similarly dismissed normative political thought. His interest in the normative aspect was masked, however, by his preoccupation with the 'scientific' task of ascertaining the historical developments that would bring into being the conditions indispensable to the realization of socialistic normative criteria.

Moreover, a crucial part of the normative content of Marxism was precisely that the working class would liberate itself - catalyzed, but not dominated, by declassed intellectuals possessed of an unclouded understanding of the historical moment. Thus, according to the Manifesto, the Communists 'do not set up any sectarian principles of their own, by which to shape and mould the proletarian movement'. ${ }^{11}$ In The Civil War in France, speaking of the I87 I Paris uprising, Marx affirmed:

The working class did not expect miracles from the Commune. They have no readymade utopias to introduce par décret du peuple. They know that in order to work out their own emancipation, and along with it that higher form to which present society is irresistibly tending by its own historical agencies, they will have to pass through long struggles, through a series of historic processes, transforming circumstances and $\mathrm{men}$. They have no ideals to realise, but to set free the elements of the new society with which old collapsing bourgeois society is itself pregnant. ${ }^{\text {I2 }}$

The French utopian socialists had drawn Marx's and Luxemburg's proper derision for attempting to devise abstractly 'the thousand concrete, practical measures, large and small, necessary to introduce socialist principles into economy, law, and all social relationships', on the basis of a decontextualized intellectualism and without any input from actual workers facing the day-to-day realities of the struggle to build socialism. For Luxemburg, they had been not merely unscientific, but conceited and undemocratic. She insisted on proceeding more modestly: "What we possess in our program is nothing but a few main supports which indicate the general direction in which to look for the necessary measures.' ${ }^{13}$

Yet Luxemburg was the last person who could have been accused of 'a criminal inattention to what one is trying to achieve', since, as will be discussed in detail further below, the same textaccused Lenin precisely of having lost sight of socialism's normative content. Lenin's policy decisions, taken in the name of socialism, were

\footnotetext{
I I. The MarX-Engels Reader, ed. R. C. Tucker (I978) (hereafter MER), 483.

I2. Ibid., at 635-6.

I3. Luxemburg, supra note io, at 69-70.
} 
fashioning a post-capitalist system that she adjudged, on the basis of her distinctively Marxian analysis, to be not socialism at all.

Marx's work contains substantial normative content that, as will be elaborated below, remains relevant even absent the confluence of historical factors that Marx expected. Still, Cohen is correct to call attention to Marx's relative inattention to normative matters, and quite perceptive about the likely reasons for that relative inattention. As Cohen points out, Marx did not believe that the revolution would occasion hard choices among normative theories, since he projected conditions to favour the adoption of policies that would at once affirm the dignity of the human person, maximize societal wellbeing, and further the fulfilment of man's 'species-essence'. Nor did he believe that fomenting revolution would require extensive efforts at moral persuasion, since material circumstances would impel an overwhelming majority to seek the overthrow of capitalism even in the absence of a fully elaborated alternative. ${ }^{\mathrm{I}}$

As Cohen indicates, Marx turns out to have been wrong on both counts. Thus, while Cohen tends to underestimate the normative content of Marx's writings, he is correct to point out that Marx's normative approach is, at the very least, incompletely articulated, and in need of augmentation. In addition, the incompleteness of Marx's normative account left a gap to be exploited, in the name of Marxism, by apologists for corrupt, tyrannical, and even horrific pseudo-socialisms that Marx, on all the evidence, would have utterly repudiated.

\section{LEGAL AND MORAL CONSTRAINT ON REVOLUTIONARY PRACTICE}

The second line of attack on the Marxian contribution to the human rights project asserts that Marxism indeed embodies a normative argument, and a bad one. There are any number of versions of this critique, but two merit special attention from the standpoint of human rights. The first is that Marxism proposes the establishment of a transitional regime of indefinite duration, a 'dictatorship of the proletariat', that is inimical to the rule of law and thus to all institutionalization of human rights. The second is that Marxism dismisses as 'bourgeois ideology' all moral principles that impose constraint on the pursuit of the revolutionary aim; the end, in short, justifies all means. Thus Marxism is alleged to represent, both procedurally and substantively, a repudiation of the very core of the human rights ethos.

\section{I. Marxism and the rule of law}

Martin Krygier argues that the absence of the rule of law under the eastern and central European regimes can be traced in significant part to Marx's analysis of the liberal state and civil society. ${ }^{15}$ He contends that Marx's tendency to view the role of law as subordinate to social forces and as a mask for ruling-class interests

\footnotetext{
I4. Cohen, supra note 4, I08-9.

15. M. Krygier, 'Marxism and the Rule of Law: Reflections After the Collapse of Communism', (I990) I 5 Law and Social Inquiry 633
} 
systematically engenders a disrespect for legality:

Many of Marx's comments on law seek to unmask it and its pretensions. As a limit to the power of the powerful it is either illusory and systematically partial - for law is involved in class exploitation and repression - or useful to ruling classes as an ideological emollient and mask for their real social power, a power which, however well disguised, is fundamental - at least, Engels came to add after Marx's death, 'ultimately', 'in the last analysis'. It was necessary, not that law fulfil any mythical essence, . . but that it disappear along with the state, and with the civil society which supported them and which they supported.

... That [law] might . . be liberating was only conceded by Marx in comparison with the feudal past or with worse versions of the capitalist present, certainly not in comparison with the socialist and communist future. So to ask Marxist revolutionaries to make space for restraint by the rule of law would be to voice a quaint liberal demand for which they were not theoretically - let alone temperamentally - programmed. ${ }^{\mathrm{I}}$

This is not an idiosyncratic charge. According to Lenin, after all, ' $\mathrm{t}$ ] $\mathrm{he}$ revolutionary dictatorship of the proletariat is rule won and maintained by the use of violence by the proletariat against the bourgeoisie, rule that is unrestricted by any laws.' ${ }^{\text {I7 }}$ In the Leninist interpretation of Marx, to exalt any of the attributes of 'bourgeois democracy' in abstraction from that system's class content was at once to mistake form for substance and to shield a class enemy bent on subverting the real democratic triumph of proletarian power. As Krygier observes, this interpretation is not confined to communist apologetics; the supposed Marxian hostility to legal restraint appears to find confirmation, for example, in the charges of apostasy that some Marxist-oriented Western scholars levelled at E. P. Thompson after the latter notoriously characterized the rule of law as an 'unqualified human good'. ${ }^{8}$

Marx never had occasion to deal directly with the question of the rule of law in the transitional society that follows the overthrow of capitalism and precedes the end stage of communism. Throughout his career, from the 1843 On the Jewish Question to the 1875 Critique of the Gotha Programme and beyond, he criticized the bourgeois-revolutionary achievements of 'political emancipation' and equal rights

I6. Ibid., at 65I (footnotes omitted).

17. V. I. Lenin, 'The Proletarian Revolution and the Renegade Kautsky' (I9I8), in The Lenin Anthology, ed. R. C. Tucker (I975), 46I, at 466. The need for this polemic against the then-leading theoretician of European Marxism itself demonstrates the controversial nature of Lenin's interpretation. At any rate, Lenin acknow ledged that 'dictatorship does not necessarily mean the abolition of democracy for the class that exercises the dictatorship over other classes'. Ibid., at 465. His answer to Kautsky emphasized both the workers' democratic participation in the soviets (councils) and their concrete realization of freedoms that had in the past been nominally guaranteed to all, but effectively enjoyed only by the bourgeoisie. Thus the new Soviet state was 'a million times more democratic than the most democratic bourgeois republic'. Ibid., at 470-I.

I8. Compare E. P. Thompson, Whigs and Hunters (I975), 258-69, with M. J. Horwitz, "The Rule of Law: An Unqualified Human Good?', (I977) 86 Yale Law Journal 56r, at 566; A. Merritt, "The Nature of Law: A Criticism of E. P. Thompson's Whigs and Hunters', (I980) 7 British Journal of Law and Society I94. Horwitz's response to Thompson is a classic:

[The rule of law] undoubtedly restrains power, but it also prevents power's benevolent exercise. It creates formal equality - a not inconsiderable virtue - but it promotes substantive inequality by creating a consciousness that radically separates law from politics, means from ends, processes from outcomes. By promoting procedural justice it enables the shrewd, the calculating, and the wealthy to manipulate its forms to their own advantage. And it ratifies and legitimates an adversarial, competitive, and atomistic conception of human relations. (Horwitz, at 566) 
as embodying an incomplete - and therefore, in a sense, false - freedom. These statements have frequently served as the bases for extrapolations rationalizing despotic concentrations of power in the name of socialist revolution.

But such extrapolations are remarkably 'undialectical'. The relentless theme of Marx's critique of liberal accomplishments is that these fail to overcome the underlying conditions that at once necessitate them and render largely illusory their benefits for the subordinate class. For Marx, the promise of these accomplishments can be genuinely realized only when the fundamental oppositions to which they respond are fully overcome. The evidence is very thin for the proposition that Marx intended - or would even have found tolerable - the abolition of legal constraints on the exercise of political power in advance of the eradication of the conditions that occasion the existence of political power itself.

In On the Jewish Question, Marx analyzed liberal rights as reflected in prominent documents from the American and French revolutions. Marx criticized the liberal conception of liberty as follows:

Liberty is ... the right to do everything which does not harm others. The limits within which each individual can act are determined by law, just as a boundary between two fields is marked by a stake. It is a question of the liberty of man regarded as an isolated monad, withdrawn into himself... [L]iberty as a right of man is not founded upon relations between man and man, but rather upon the separation of man from man. It is the right of the circumscribed individual, withdrawn into himself. ${ }^{\text {I9 }}$

The practical application of this asocial liberty, Marx maintained, reduces to the right to private property, which consists in 'the right to enjoy one's fortune and to dispose of it as one will, without regard for other men and independently of society. It is the right of self-interest. ${ }^{20}$

For Marx, this impoverished conception of liberty reflected the essential contradictions of bourgeois political life. The French Declaration of the Rights of Man and of the Citizen drew the distinction between 'man', a member of civil society, ${ }^{21}$ on the one hand, and 'citizen', a member of the political community, on the other. Marx discerned in this distinction a thorough subordination of the political community to civil society, to the arena of private interest and egoism. 'The end of every political association', stated the Declaration, 'is the preservation of the natural and imprescriptible rights of man.' All of the 'rights of man,' Marx observed, concerned the 'individual separated from the community, withdrawn into himself, wholly

I9. MER, supranote II, at 42 .

20. Ibid.

2I. The term 'civil society' is a source of great confusion. Marx, following Hegel, used that term to demarcate a realm of social life within which individuals pursue their private interests, as distinct from 'political community' (for Hegel, 'the state'), a realm in which they pursue a common good. (This is an oversimplification, but a useful one.) Since the I980s, however, the term has come to denote, especially in regard to Eastern Europe, a realm of civic association developing independently of the tentacles of the totalitarian state. These two uses of 'civil society' have overlapping elements, and it is frequently (but quite wrongly) imagined that Marx championed the crushing of civil society, in both senses, by the all-powerful socialist state. Thus arises Krygier's assertion that Marx was hostile 'not to particular aspects of civil society, but to civil society tout court', that he 'hated and considered rightly doomed what the whole of eastern Europe is now wondering how to build or rebuild'. M. Krygier, 'Marxism, Communism, and Narcissism', (I990) I5 Law and Social Inquiry 707, 7 17. This assertion is, to put it mildly, highly misleading. 
preoccupied with his private interest and acting in accordance with his private caprice." ${ }^{22}$ Such a vision of political association assumes that ' $t$ ] he only bond between men is natural necessity, need and private interest, the preservation of their property and their egoistic persons.'23

Liberal institutions establish a political community that exists only as means of preserving the prerogatives of egoism, so that 'species-life itself - society - appears as a system which is external to the individual and as a limitation of his original independence'. Man there functions as a species-being only in an 'allegorical' sense, in the abstract role of citizen that is subordinated to his concrete role as a self-seeking individual. Accordingly,

we observe that the political liberators [liberals] reduce citizenship, the political community, to a mere means for preserving these so-called rights of man, and consequently, that the citizen is declared to be the servant of egoistic 'man', that the sphere in which man functions as a species-being is degraded to a level below the sphere where he functions as a partial being, and finally that it is man as a bourgeois and not man as a citizen who is considered the true and authentic man. ${ }^{24}$

Genuine human emancipation, to the contrary, requires a supersession of this opposition, so that 'the real, individual man has absorbed into himself the abstract citizen', and the 'individual man, in his everyday life, in his work, and in his relationships, ... has become a species-being'. ${ }^{25}$ The achievement of genuine human freedom for Marx depends on 'the return of man himself as a social, i.e., really human, being, a complete and conscious return which assimilates all wealth of previous development'. This entails nothing less than 'the genuine resolution of the conflict between man and nature and between man and man'. ${ }^{26}$ In Marx's conception, rights, like the state itself, ultimately disappear as a result of elaborate historical processes, not simple acts of will. Indeed, as he noted in Critique of the Gotha Programme, even bourgeois economic rights, such as the right to payment according to one's work, remain and cannot be transcended until the development of productive forces and 'the all-round development of the individual' make possible the fulfilment of the formula, 'from each according to his ability, to each according to his needs'. ${ }^{27}$ There is thus no reason to assume that civil and political rights (corresponding to the historical circumstances of socialist revolution) can be transcended before all opposing interests, and thus all need for coercion (and, therefore, for the state itself, as history has known it), are themselves transcended. ${ }^{28}$

22. MER, supra note II, at 42.

23. Ibid., at 43 .

24. Ibid.

25. Ibid., at 3I. The point was not to disparage 'political emancipation', but to expose its limitations: 'Political emancipation certainly represents a great progress. It is not, indeed, the final form of human emancipation, but it is the final form of human emancipation within the framework of the prevailing social order. It goes without saying that we are speaking here of real, practical emancipation.' Ibid., at 35 .

26. K. Marx, 'Economic and Philosophic Manuscripts of I 844', in MER, supra note I I, 66, at 84.

27. K. Marx, 'Critique of the Gotha Programme', in MER, supra note II, 525, at 53 I.

28. Engels characterized the transitional state as 'at best an evil inherited by the proletariat' whose 'worst sides' are to be 'lopped off', but that will persist in some form 'until such time as a generation reared in new, free social conditions is able to throw the entire lumber of the state on the scrap heap'. F. Engels, 'Introduction to The Civil War in France', MER, supra note II, at 629. 
More concretely, for Marx, unlike for many of his self-appointed continuators, working-class power was not an abstraction. The 'dictatorship of the proletariat' entailed the actual control by ordinary people of government operations on a day-to-day basis. Indeed, such control, as Marx described in his account of (-cum-projection upon) the I 87 I Paris Commune, ${ }^{29}$ was not to be limited to the workers, but extended to the peasantry as well, notwithstanding the latter's distinct set of interests:

The rural communes of every district were to administer their common affairs by an assembly of delegates in the central town, and these district assemblies were again to send deputies to the National Delegation in Paris, each delegate to be at any time revocable and bound by the mandat impératif(formal instructions) of his constituents.... While the merely repressive organs of the old governmental power were to be amputated, its legitimate functions were to be wrested from an authority usurping pre-eminence over society itself, and restored to the responsible agents of society. Instead of deciding once in three or six years which member of the ruling class was to misrepresent the people in Parliament, universal suffrage was to... [permit the people] if they for once make a mistake, to redress it promptly. ${ }^{30}$

'The Commune', Marx believed, 'would have delivered the peasant of the blood tax - would have given him a cheap government - transformed his present bloodsuckers, the notary, advocate, executor, and other judicial vampires, into salaried communal agents, elected by, and responsible to, himself.' ${ }^{\text {I }}$ To himself literally, it may be added, not merely 'objectively', as in subsequent communist distortions of the concept of representation.

True accountability of the revolutionary state apparatus to the working class requires that citizens be protected against that apparatus. Engels's i 89 I 'Introduction' to Marx's account of the Paris Commune contains a derisive description of a vanguardist faction among the Communards, the Blanquists:

Brought up in the school of conspiracy, and held together by the strict discipline which went with it, they started out from the viewpoint that a relatively small number of resolute, well-organized men would be able, at a given favourable moment, not only to seize the helm of state, but also by a display of great, ruthless energy, to maintain power until they succeeded in sweeping the mass of the people into the revolution and ranging them round the small band of leaders. This involved, above all, the strictest, dictatorial centralization of all power in the hands of the new revolutionary government. ${ }^{32}$

Engels therefore warned that the working class must 'safeguard itself against its own deputies and officials, by declaring them all, without exception, subject to recall at any moment'.33

It follows that, notwithstanding their bourgeois origins, political rights retain their relevance, at least in some form, well beyond the overthrow of the bourgeoisie.

29. As Shlomo Avineri points out, 'despite its superficial appearance as a narrative of the Commune's achievements', The Civil War in France was more an account of what Marx took to be its potential achievements. S. Avineri, The Social and Political Thought of Karl Marx (I 968), 24I. Marx did not (Engels's subsequent exuberance notwithstanding) regard the uprising as the true dawn of socialist revolution (the term 'Commune', it should be noted, referred not to communism but to the historical name of the Paris municipal government), but he did seize the opportunity to project the initial direction of such a revolution. See ibid., at I98-20I, 239-49.

30. K. Marx, The Civil War in France, in MER, supra note II, at 6I8, 635-36.

3I. Ibid., at 633 .

32. Engels, supra note 28 , at $626-27$.

33. Ibid., at 627. 
And indeed, one finds nowhere in Marx's critique of the French Declaration of the Rights of Man and Citizen any attack on the rights of citizens, which included the right to 'speak, write and publish freely' (Art. XI) and the 'right to determine the necessity of the public contribution, either in person or by their representatives, to consent freely thereto, to watch over its use, and to determine the amount, base, collection and duration thereof' (Art. XIV). ${ }^{34}$ To the contrary, just a year before writing $O n$ the Jewish Question, Marx condemned Prussian censorship in terms that extended, beyond the immediate context, to the period of French revolutionary rule, for which he had the most sympathy:

The writer is exposed to the most dreadful terrorism, the jurisdiction of suspicion. Tendencious [sic] laws, laws that do not supply objective norms, are laws of terrorism, as they were thought out by the necessity of the state under Robespierre and by the corruption of the state under the Roman emperors. Laws that take as their criteria not action as such, but the state of mind of the actor, are nothing else than the positive sanction of lawlessness. 35

Rosa Luxemburg's criticisms of the early course of the Bolshevik revolution thus appear as fully authentic emanations from what little of the Marxian canon pertains to an anti-capitalist dictatorship established by a revolutionary clique claiming to represent the objective interests (and the latent will) of the proletariat. She proclaimed:

Freedom only for supporters of the government, only for the members of one party however numerous they may be-is no freedom at all. Freedom is always and exclusively for the one who thinks differently. Not because of any fanatical concept of 'justice' but because all that is instructive, wholesome and purifying in political freedom depends on this essential characteristic, and its effectiveness vanishes when 'freedom' becomes a special privilege..$^{6}$

While she did not shrink from harsh measures to extirpate the old regime, Luxemburg objected to the exclusion of any substantial part of the populace, proletarian or not, from political participation. She called for 'unrestricted freedom of press and assembly', and faulted Lenin's failure to allow for 'the most unlimited, the broadest democracy and public opinion'. ${ }^{37}$ She recognized that in the absence of pluralism, popular participation is necessarily reduced to the role of rubberstamping the leadership's decisions:

Without general elections, without unrestricted freedom of press and assembly, without a free struggle of opinion, life dies out in every public institution, becomes a mere semblance of life, in which only the bureaucracy remains as the active

34. Marx pointed out that under the French constitution, freedom of the press is denied 'when it endangers public liberty'. This, for Marx, is another example of how liberalism subordinates the rights of the citizen to the imperative of preserving 'the rights of man', i.e., order in 'civil society', by which Marx meant the realm of competitive self-seeking. K. Marx, 'On the Jewish Question', in MER, supra note II, 44.

35. K. Marx, 'Notes about the New Prussian Censorship Regulations' [1842], quoted in S. Avineri, The Social and Political Thought of Karl Marx (I968), I88; cf. Charles de Secondat, Baron de Montesquieu, The Spirit of the Laws [I748], ed. A. Cohler, B. Miller and H. Stone (I989), I98 (bk. XII, ch. I2) (vagueness of speech crimes destructive of liberty).

36. Luxemburg, supra note io, at 69 .

37. Ibid., at 7 I. 
element.... [What remains is] not the dictatorship of the proletariat,... but only the dictatorship of a handful of politicians, that is[,] a dictatorship in the bourgeois sense. ${ }^{38}$

Even Leon Trotsky, a central target of Luxemburg's criticisms, belatedly came to embrace Luxemburg's as the genuine Marxist view (without, however, conceding that he and Lenin had been any more dictatorial than had been required by the dire exigencies of the years immediately following 1917). In 1936, the exiled Trotsky denied (albeit now rather conveniently) that the abolition of conflicting classes had removed any need for competing parties. To the Stalinist argument that 'the question where to go - whether back to capitalism or forward to socialism - is no longer subject to discussion', Trotsky answered that the 'choice of road is no less important than the choice of the goal', and that the Soviet working class could 'furnish adequate nourishing soil for several parties'. Quoting Victor Serge, he asked, 'What remains of the October Revolution ... if every worker who permits himself to make a demand, or express a critical judgment, is subject to imprisonment?'39

And yet, whatever arguments for democratic accountability might be authentically derived from Marxian texts, Krygier is correct that, historically speaking, Marxism has furnished few resources to the struggle against the usurpations and brutalities of vanguardist dictatorships that ruled in its name. ${ }^{40}$ This deficit is familiarly, and not altogether incorrectly, attributed to the Marxian fixation on economic divisions and dynamics as the factors ultimately driving political events. The danger that an autonomous political force might wrest control of both the state and the economy for its own ends simply did not occupy Marx's attention - even though, as Michael Harrington has pointed out, Marx had recognized explicitly that under pre-capitalist conditions (e.g., 'Asian despotism'), it is political power that determines the mode of economic life. ${ }^{41}$

Ironically, Marxism's relative inattention to the danger of vanguardist usurpation can be attributed not to Marx's lack of familiarity with would-be vanguardist usurpers, but to the contempt for them that his familiarity bred. Marx was, indeed, intensely occupied with neo-Jacobin and Blanquist efforts to remake societies by force of political will. His 'scientific' approach to social transformation led him to view these efforts as doomed to futility. ${ }^{42}$ His concern for their consequences was that they would lead the proletariat to premature uprisings, resulting in catastrophic

38. Ibid., at $7 \mathrm{I}-2$.

39. L. Trotsky, The Revolution Betrayed (1972), 268-70.

40. Krygier's critique has both the strength and the weakness that it focuses on the 'Marxism' that has had a distinctive historical impact in its own name, at the expense of other variants, such as those that blended with liberalism to produce mainstream continental European social democracy. That focus leads him to count Lenin, Trotsky, and even Stalin as authentic continuators of Marxism, largely on the ground that they and their supporters sincerely believed them to be so. Krygier, supra note 2I, at 707, 708 (his response to critics of the article cited above). Reading Marx through this lens, however, tends to overdetermine Krygier's conclusions, since communist interpretations of Marx were fashioned to reflect their authors' policy objectives, and thus could scarcely be expected to emphasize any politically inconvenient aspects of the underlying theory.

4I. M. Harrington, The Twilight of Capitalism ( 1976 ), 84-7. As Harrington notes, Stalin suppressed discussion of Marx's work in this area, precisely because it might have provided the basis for an indictment of Stalinist. practice. Ibid., at 87 .

42. See Avineri, supra note 29, at i 87-8 ("Marx explains the reign of terror as derived from the Jacobin attempt to realize a political order still lacking its socio-economic preconditions .... Recourse to terror is, according to Marx, an ultimate proof that the aims the revolution wishes to achieve cannot be achieved at present'). 
defeats (and thus, setbacks for the revolutionary timetable). The suggestion that they would cause catastrophe through success did not quite arise.

Even Engels's berating commentary on the Commune's would-be usurpers, cited above, neglected to be alarmist; his faith in a historical telos caused him to regard dictatorial conspiracies more as irrelevant than as dangerous. Indeed, for Engels, the experience of the Commune demonstrated Blanquism to be as superfluous in the presence of material conditions for a genuine revolutionary development as it had been futile in the absence of such conditions. According to Engels, the 'irony of history willed' that the Blanquists in Paris did just the opposite of what their doctrine prescribed: in power, their dictatorial stance gave way to a call for a free federation of Communes and to the filling of all posts by universal suffrage with right of recall. ${ }^{43}$ Engels's point was that the Commune, though led by non-Marxists with dubious theoretical credentials, inexorably found its way, driven by the forces of history, to the very democratic dictatorship of the proletariat prescribed by Marx. The problem solves itself.

A further difficulty is the vagueness of the primary literature's references to 'dictatorship of the proletariat'. Dictatorship classically denoted a constitutional republic's delegation, for a limited period, of all powers needed to address an emergency;4 it thus involves, as Lenin suggested, 'rule that is unrestricted by any laws'. Even Lenin limited this characterization to the relationship between proletarian political power and recalcitrant elements of the bourgeoisie. The dictatorship is to be exercised by the proletariat as a whole, for the sole purpose of assimilating elements of other classes to the universal class. This animating purpose implies that one's political role, rather than one's class origin, governs one's relationship to the dictatorship. As noted above, non-hostile elements from other classes, such as the peasantry, are participants in, not objects of, the dictatorship; in principle, this is true even of members of the bourgeoisie, as soon as they renounce their class identity. The implication is that the relationship of rulers to ruled, initially presented as a matter of class, is transformed into a matter of 'objective' role in a teleological process.

That implication arguably entails, however, that where members of the working class are deemed to be 'objectively' aligned with the bourgeois enemy - where they lack the consciousness that transforms the 'class in itself' into a 'class for itself'- they may properly be objects of, rather than participants in, the exercise of dictatorial authority ${ }^{45}$ Even worse, the 'proletariat' may be covertly transmogrified into a wholly

\footnotetext{
43. Engels, supra note 28 , at $626-8$.

44. See N. Machiavelli, The Discourses [I52 I] (I970), I95 (bk. I, disc. 34); C. Schmitt, Political Theology [I922](I985), 5-IO; G. Schwab, The Challenge of the Exception (1989), 30-7.

45. It thus became possible for Trotsky to assert in I 92 I that 'the dictatorship does not base itself at every given moment on the formal principle of a workers' democracy, although the workers' democracy is, of course, the only method by which the masses can be drawn more and more into the political life'. The Party, he concluded, had the right 'to assert its dictatorship even if that dictatorship temporarily clashed with the passing moods of workers' democracy'. R. Miliband, Marxism and Politics (I977), I43, citing I. Deutscher, The Prophet Armed (I954), 509. Even Lenin's foremost rival among Russian Marxist theoreticians, Georgy Plekhanov, affirmed that "The success of the revolution is the highest law. And if, for the sake of that success, it would be necessary temporarily to limit the application of one or another democratic principle, it would be a crime to shrink from such a restriction.' G. Plekhanov, Minutes of the Second Congress of the Russian Social Democratic Labor Party (I957), I82, quoted in R. A. Medvedev, The October Revolution, trans. G. Sanders (I979), II3.
} 
non-empirical construct, constituted not by real workers but by an 'objectively correct' set of normative commitments. ${ }^{46}$ Historically, this is the sleight-of-hand that often turned Marxism, ironically, into a rationalization for the very Blanquiststyle despotism that Marx and Engels expressly scorned. Marx and Engels never engaged in this manoeuvre, and there is little reason to believe that they would have approved of it, but they seem unwittingly to have laid the groundwork for it.

Marx and Engels can be forgiven for failing to anticipate an issue that arose only after their deaths, so long as their work provided a basis upon which an appropriate response could be worked out. Yet it remains possible that, as Krygier puts it, Marxists were 'not theoretically-letalone temperamentally-programmed' to address the issue appropriately. Self-styled followers of Marx and Engels have been drawn, again and again, to undemocratic or terroristic means. It thus remains to ask whether Marxian thought, in neglecting the issue, leaves room for an affirmative renunciation of such means.

\subsection{The ends and the means}

Steven Lukes has posed directly the question, 'Can a Marxist believe in human rights?'47 He concludes that 'central elements of the Marxist canon ... are incompatible with such a belief'. ${ }^{48}$ His argument for this conclusion, however, dubiously imputes to the human rights project a privileged role for the deontological conception of morality.

According to Lukes, "the real test of a belief in human rights comes when the goals of the struggle or strategy come into conflict with the defence of rights claims. ${ }^{49}$ This view of human rights is widely held, but it rests on a highly questionable proposition: that 'the defence of rights claims' is qualitatively different from, and therefore capable of taking categorical priority over, 'the goals of a struggle or strategy'. Of course, where 'the goals of a struggle or strategy' represent a particularist interest or an idiosyncratic conception of the common good that can be counterposed to genuine universal principles, the proposition appears sound. It would be appalling, on any account, to assert as a moral precept that 'My parochial end justifies any means that maximizes the likelihood of that end's fulfilment.' The difficult questions, however, arise where the satisfaction of one set of vital human interests can occur only at the expense of another set of vital human interests.

The dominant approach of contemporary human rights scholars-that of Kantian, or deontological, ethics - contains an anomaly that has been widely underappreciated. On the one hand, the term 'deontological' is used in political philosophy to mark a distinction from 'teleological' approaches. Teleological approaches derive political norms from 'the good': the nature of the good life that the political project

46. One is reminded of Bertolt Brecht's poem facetiously suggesting, amid the I953 East German uprising, that since 'the people had forfeited the confidence of the government', the solution was for the latter to 'dissolve the people and elect another'. B. Brecht, 'The Solution', available at http:/www.revolutionarydemocracy. org/rdv4n2/brecht.htm.

47. S. Lukes, Moral Conflict and Politics (I99I), I73-88.

48. Ibid., at 188 .

49. Ibid. 
seeks to realize for human beings..$^{\circ}$ In contrast, the deontological approach affirms the priority of 'the right': the entitlement, indefeasibly possessed by each individual affected by the project, to be treated in accordance with his or her inherent worth and capacity for self-directed activity. ${ }^{5 \mathrm{I}}$ In positing inviolable rights as directly deducible from the dignity of the human subject, deontologists are thought to 'take rights seriously' in a way that communitarians, utilitarians, and perfectionists do not.

Be this as it may, the rights exist for the sake of the right-bearer, and their concrete existence - that is to say, the effective capacity of the bearer to exercise them is a matter of the empirical conditions facing the right-bearer in a given instance. The rights-oriented political project is thus to create and to maintain the systematic prevalence of those conditions; the project cannot be defined other than by its intended consequences.

However, in the realm of moral philosophy, 'deontology' is opposed to 'consequentialism'. ${ }^{2}$ Here again, the emphasis of 'deontology' is on the subject rather than the object, and again the dignity of the human person is stressed. Here, however, the agent, not the right-bearer, is the subject; 'agent-centred morality', as it is frequently called, focuses on duties, not rights. This may not initially seem important, since rights and duties can appear to be two sides of the same coin, rights giving rise to the very duties that moral deontology exalts; the Kantian categorical imperative can be rephrased to demand that the agent not violate another's human rights. In fact, however, the Kantian categorical imperative seems insufficient to the task of 'taking rights seriously'.

In human rights law there are four types of duties to which rights give rise: (i) duties to respect (negative rights giving rise to negative duties); (ii) duties to protect (negative rights giving rise to affirmative duties); (iii) duties to ensure (affirmative rights giving rise to affirmative duties); and (iv) duties to promote (negative and affirmative rights giving rise to affirmative duties of a less determinate character). ${ }^{53}$ Agent-centred morality gives unconditional priority to one type of duty: the duty to respect, or to refrain from violating, rights. But if our concern is for the

50. The term 'teleological', as used in this context, refers only to a telos inherent in purposely devised norms and institutions, and not specifically to the imputation of a telos to historical developments more generally, as in the Hegelian dialectic.

5I. See, e.g., R. A. Dworkin, A Matter of Principle (I985), I8I-204, emphasizing as a defining characteristic of liberalism a scrupulous 'neutrality' in regard to citizens' diverse views of the proper objects of human striving. Dworkin contrasts liberalism with the view that 'the treatment government owes citizens is at least partly determined by some conception of the good life', a view he associates with both 'American conservatism and various forms of socialism or Marxism'. Ibid., at I92. Although a 'perfectionist liberal' school has arisen to take issue with this neutralist approach to liberalism, see, e.g., W. A. Galston, Liberal Purposes (I99I); G. Sher, Beyond Neutrality: Perfectionism and Politics (I997), current theorists of the left have been slower to acknowledge a distinctive conception of the good, repelled as they are by the thought of even so abstract a kinship to conservatism, and disposed as they are to the limitless appreciation of 'difference'.

52. In $A$ Theory of Justice (I97 I), John Rawls was careful to distinguish between the two uses of this term, but did not pursue the question of their relationship. Ibid., at 30. Immanuel Kant is the source of both concepts, and he clearly understood them to be closely related. See M. Sandel, Liberalism and the Limits of Justice (I982), 4. Human rights scholarship has not, to my knowledge, focused directly on the question, but seems generally to assume that the two concepts go together.

53. These categories are owing to G. I.H. Van Hoof, "The Legal Nature of Economic, Social, and Cultural Rights: A Rebuttal of Some Traditional Views', in P. Alston and K. Tomasevski (eds.), The Right to Food (1984), 97; see also H. Shue, Basic Rights: Subsistence, Affluence, and US Foreign Policy (I980), 35-64 (human rights entail correlative duties of protection and assistance, as well as non-deprivation). 
right-bearer, rather than for the agent's soul, this categorical priority seems unjustified. Especially where there are systemic deprivations of the conditions of a dignified human existence, a thorough-going struggle for human rights - even such rights as derived from deontological premises - cannot easily be reconciled with a moralistic affirmation that 'evil shall come into the world, but not through me'. Thus the political project is fraught with moral ambiguity.

At the core of the current-day human rights movement is the quest to bring about the conditions of a dignified human existence. Human rights thus entail not merely duties to avoid violating human dignity by discrete and direct acts of violence, but further duties affirmatively to protect the right-bearer from violence and from analogous inflictions with similarly dehumanizing effects. Beyond those lie duties to take all necessary measures to secure for all right-bearers (within the limits of what is materially feasible) the conditions that permit human potentialities to be realized. The proliferation of internationally certified human rights - now encompassing 'first-generation' civil and political rights well beyond the inviolability of the physical integrity of the person, 'second-generation' economic and social rights, and 'third-generation' collective rights to the minimal conditions of societal flourishing - represents a series of efforts to correct for the manifest inadequacy of simple negative imperatives. ${ }^{54}$

Human rights are typically characterized as a priori constraints on the pursuit of political ends. The more holistically rights claims address human dignity, however, the more inexorably and expansively do they appropriate the space of politics. Invocation of the term 'human rights' altogether fails to pre-empt political contestation, because competing views of how to prioritize and how to accomplish the posited ends constitute the very core of politics. ${ }^{55}$

Deontological liberals have made various efforts to square the circle. The conventional solution is to posit a set of categorical priorities among universal human interests, emphasizing interests that depend on holding the state at bay (i.e., negative rights connected to negative state duties, such as freedom from arbitrary arrest or from censorship) over interests that depend for their fulfilment on the vigorous exercise of state power to create the needed social conditions (i.e., negative and affirmative rights connected to affirmative state duties, such as protection from crime and subversion or provision of adequate food, shelter, health care, and education). Even those deontological liberals highly committed to the latter set of interests tend to rule out furthering them in ways that compromise the former set. But it is not clear that these categorical priorities can be justified; even Rawls, who famously posits a 'lexical' priority of his first principle of justice (civil and political liberty) over his second principle (equity of distribution), conditions that priority on the satisfaction of basic material needs. ${ }^{6}$

54. One can, of course, reject this proliferation, and insist that only 'first-generation' rights should be considered human rights. See M. Cranston, 'Are There Any Human Rights?', (I983) II2 Daedalus I. That insistence, however, has not gained wide acceptance in the contemporary human rights movement.

55. Ronald Beiner explores the consequences of this reality for 'rights talk' in What's the Matter with Liberalism? (I992), at 80-97; see also J. Gray, Two Faces of Liberalism (2000), at 69-I04 (pointing out that core liberal values are regularly in conflict with one another).

56. Rawls, supra note 52 , at $60-5,302-3,542-3$. 
It is currently fashionable to argue, given the patent abuse of arguments to the contrary by tyrannical regimes, that there are no systematic clashes among the internationally recognized rights. But unless one has a deep-seated (and supra-rational) faith in a morally ordered universe in which all virtues are mutually reinforcing, it can hardly be denied that the question of their clash is an empirical one in every given instance. The argument would not be that civil and political rights interfere with economic and social rights as a general matter (the straw position that is typically posed for refutation), but rather that in a given instance, respect for certain negative rights will unjustifiably block the fulfilment of other vital human interests that can equally be expressed in the language of rights. At any rate, positing the absence of a practical contradiction, for liberal no less than for Marxian theorists, evades the responsibility to guide conduct in the presence of such a contradiction.

Lukes offers a more sophisticated response, emphasizing the incommensurability of the human costs and benefits at issue. 'On the one hand, we endorse and pursue the attainable good; on the other, we condemn and regret the uncancelled wrongs committed in its pursuit.' ${ }^{57}$ This position acknowledges the force of Robert Nozick's orthodox deontological insistence on rights as 'side-constraints'. For Nozick, individual rights may not be violated in the name of a greater social good because there

is no social entity with a good that undergoes some sacrifice for its own good. There are only individual people, with their own individual lives. Using one of these people for the benefit of others, uses him and benefits the others... To use a person in this way does not sufficiently respect and take account of the fact that he is a separate person, that his is the only life he has. He does not get some overbalancing good from his sacrifice. ${ }^{5}$

Although rejecting Nozick's absolutism, Lukes regards an appreciation of its underlying premise as crucial to 'any adequate account of human rights'. He concludes that '[i]t is vital to keep alive the sense, among politicians and citizens alike, that deception, betrayal, and worse, when they are committed for the public good, violate morally important principles and commit uncancelled wrongs'.59 He regards Marxism as incompatible with this position, since it 'one-sidedly rules out or ignores, in the assessment of human action and character, all that it holds out to be irrelevant to the project of human emancipation' ${ }^{60}$

The validity of Lukes's assessment turns on the ambiguity of the term 'uncancelled wrongs'. Agent-centred morality is primarily concerned with wrongs that the agent commits, whereas the human rights project is primarily concerned with wrongs that the right-bearer suffers. If the two are merely two sides of the same coin, with

57. Lukes, supra note 47, at I92-3. He goes on to say: 'Machiavelli captured this dual structure perfectly when he said that in such cases, "while the act accuses, the result excuses".' Ibid., at I93. Taken literally, the quotation suggests a meaning that Machiavelli, in my reading, did not intend. As a term of art, 'excuse', while sheltering the actor from blame on ground of diminished agency, concedes that the act is unjustifiable and ought not to have been done. See J. Dressler, 'Exegesis of the Law of Duress: Justifying the Excuse and Searching for its Proper Limits', (1989) 62 Southern California Law Review I33I, I 349 n. I24. Such was not Machiavelli's position on ruthless acts.

58. R. Nozick, Anarchy, State and Utopia (I974), 32-3, quoted in Lukes, supra note 47, at I78.

59. Lukes, supra note 47 , at $196-7$.

6o. Ibid., at 208-9. 
every wrong suffered directly implying a wrong committed, then any belief system compatible with human rights must affirm the wrongfulness of acts that, even if accurately calculated to achieve for the great many the indispensable conditions of a dignified human existence, trample the rights of the few.

Marxism concededly fails this test. When Marx spoke of a 'categorical imperative to overthrow all those conditions in which man is an abased, enslaved, abandoned, contemptible being, ${ }^{61}$ his purpose was to shift the focus of moral discourse from individual to systemic deprivations of the conditions of a dignified human existence. Trotsky, in Their Morals and Ours, an otherwise crude polemic on revolutionary morality, was being true to Marx at least in asserting, 'That is permissible ... which really leads to the liberation of humanity'; the revolutionary end, by reference to which any means must be judged, 'is justified if it leads to increasing the power of humanity over nature and to the abolition of the power of one person over another'. ${ }^{62}$ Accordingly, Trotsky was able to invoke the unsentimental consequentialism manifested in Marx's robust defence of the Communards' decision to hold and shoot hostages. ${ }^{63}$

It is nonetheless quite tendentious to assert that in abjuring tortured sentimentalism (to use words that he might have chosen), Marx disqualified himself as a contributor to the human rights project. Nothing in Marx's understanding of the essential qualities of the human person, or in his characterization of the relationship between the individual and society, is inconsistent with regarding indignities suffered in any context - including at the hands of the revolution - as 'uncancelled wrongs', in the sense of humanly caused harms that no one should have to incur, and that are in no way nullified by countervailing societal benefits.

What would not have followed, for Marx, is that the revolutionary acts inflicting these indignities thereby constitute 'uncancelled wrongs'. Marx perceived the infliction of indignities not as isolated acts by which wilful individuals disrupt a harmonious normality, but as systemic products of the conflictual historical processes that animate every epoch. Indeed, Marx's analysis of capitalism operates precisely to attribute responsibility for its indignities not to individual capitalist taskmasters, but to a system within which those taskmasters are themselves trapped. The indignities suffered are to be redressed neither by sermonizing at nor by taking retribution against their immediate (and mainly nominal) agents - nor even by railing against 'injustice', since the baselines of 'justice' are set by the existing patterns of social relations - but by transforming the processes that pit human beings against one another. Any distraction from that task was a source of his exasperation.

In the Marxian view, 'bourgeois morality', by normalizing the violence associated with the operation and maintenance of the bourgeois order, and by identifying as exceptional the violent response occasioned by that very order's contradictions, functions 'ideologically' to distort the moral picture. The latter violence it identifies as 'wrongs', whereas the former, however incommensurable the associated human

6I. Marx, Introduction to the Contribution to the Critique of Hegel's Philosophy of Right, in MER, supra note II, at 60.

62. L. Trotsky, 'Their Morals and Ours' [1938], in L. Trotsky, J. Dewey and G. Novak, Their Morals and Ours: Marxist vs. Liberal Views on Morality (1973), I3, 48.

63. Ibid., at 39 . 
costs, it classifies as 'mere' harms, inflicted without bad will. (An example is the 'double-effect' rule often said to govern the problem of collateral damage in warfare.) The pain of the victims-in-focus obscures the pain of a great many more victims hidden, as it were, in plain sight. Thus handwringing over the human costs of acts genuinely necessary to bring to an end the systematic abasement and enslavement that capitalist ideology normalizes undoubtedly struck Marx as pointless, if not debilitating. ${ }^{64}$

There are, perhaps, good reasons to be troubled by so unsentimental an approach. Sociologically speaking, a less straightforward acceptance of ruthlessness may well help to inhibit the unnecessary adoption of harsh means. The philosophical objections, however, are not so easy to sustain.

The idea that a wrong suffered necessarily implies a wrong committed operates from the unacknowledged premise of a morally ordered universe - a natural harmony in opposition to the Marxian baseline of contradiction and conflict - in which deontological and consequentialist moralities are mutually reinforcing. Lukes himself indicates that he rejects such a teleology, ${ }^{65}$ much as he rejects the 'dialectical' teleology, endemic to deterministic readings of Marx, that similarly obviates the hard questions. But being unwilling to choose, he is left with the moral conclusion that the same act both should and should not be undertaken. Even if this position is somehow philosophically defensible (and I will not here digress to defend my strongly held view that it is not), ${ }^{66}$ it seems implausible that so convoluted a position is an essential element of the human rights project.

Once again, however, there remains a real problem that is masked by the illusory one. As expressed in Trotsky's maxim, 'That is permissible ... which really leads to the liberation of humanity', Marx's consequentialism laid the foundation for the consistent repudiation of extreme measures on the ground of inefficacy. Historical materialism's 'obstetric' account of revolutionary practice revealed excesses of insurrectionary ruthlessness as indicative of the insurrection's prematurity. In the dialectical model (which served as a Marxian counterpart to the more conventional morally-ordered-universe prejudice), the urge to excessive ruthlessness was the conclusive evidence of its own futility. The seeming power of this argument rendered a more searching examination of revolutionary morality largely moot.

But subsequent efforts to implement Marx's vision implicitly abandoned Marx's dialectical faith. Lenin, finding the proletariat diverted from consciousness of its historical role, augmented the catalytic function of the revolutionary vanguard, purporting to find a role within historical materialism for elite exertions of heroic

64. One might take the point still further and say that the revolutionary actor is, in some sense, not the true author of the violence inflicted on his victims. I imagine, though, that even Lenin and Trotsky would have repudiated this suggestion as a cowardly inversion of the hypocritical moralizing that they castigated.

65. Lukes indicates an acknowledgment that under certain conditions the demands of deontological morality must give way. Lukes, supra note 47 , at I 78 , I93.

66. There is a substantial literature on the 'dirty hands' problem, that metaphor being intended to imply that the moral need to commit the ruthless act does not remove the moral stain of having committed it. Appreciation of this paradox is often taken as a mark of sophistication and sensitivity. Nonetheless, the posited paradox opens the door to a hypocritical evasion of moral responsibility, wherein beneficiaries of ruthless acts can at once wish for the acts to be undertaken and participate (or at least acquiesce) in the castigation of the perpetrators. I find it difficult to see how this stance strikes a blow for rectitude, political or personal. 
will. Though he could not admit it, his project was to reconcile Marx with the authoritatively discredited Auguste Blanqui. ${ }^{67}$ In so doing, he transformed moot moral questions into live ones.

Just as importantly, although the possibility of achieving revolutionary change by peaceful and incremental means repeatedly waxes and wanes in the writings of Marx and Engels, Lenin one-sidedly dismissed those writings that might have problematized his determination to pursue insurrection. He thereby overemphasized language in the primary literature that suggested a repudiation of all intermediate goals. For Lenin, the stark alternative to the revolutionary triumph's secular version of salvation was perdition; there was literally 'nothing to lose', either strategically or morally.

This framework occasioned a very crude understanding of the moral choices confronting the revolution, as reflected in Trotsky's lamentable Their Morals and Ours. Trotsky there affirmed that 'not all means are permissible', but his critical examination extended only to means that reveal corrupted ultimate ends (referring, of course, to the Stalin regime). ${ }^{68}$ It did not extend to measures that, although oriented towards the proper ultimate end, exact appalling human costs for the sake of a merely speculative contribution to that end's realization. His consequentialist inquiry is thus highly incomplete and distorted.

The esteemed liberal-pragmatist John Dewey, in commenting on Trotsky's polemic, observed as follows:

Since the class struggle is regarded as the only means that will reach the end, and since the view that it is the only means is reached deductively and not by an inductive examination of the means-consequences in their interdependence, the means, the class struggle, does not need to be critically examined with respect to its actual objective consequences. $^{69}$

This distortion, Dewey explained, leads inexorably to 'the position that the end-inview (as distinct from objective consequences) justifies the use of any means in line with the class struggle and that it justifies the neglect of all other means. ${ }^{70}$

Though Marx apparently never addressed this issue, it is difficult to imagine him repudiating Dewey's mode of reasoning, as it bears an uncanny resemblance to Marx's own. Fond as Marx was of grandiose generalizations (including invocations of the supposed dialectic of history), he characteristically insisted that all such

67. It was no accident that Lenin named his pathbreaking I 902 organizational tract, What Is to Be Done?, after an 1862 Russian populist novel of revolutionary heroism. N. Chernyshevsky, What Is to Be Done? (I983). The significance of Chernyshevsky's novel centres on the character Rakhmetov, a specimen of those men, 'few in number,... the moving spirits behind all others, the very salt of the salt of the earth'. Ibid., at 320-I. Such men eliminate from their lives 'all luxury and caprice'; 'the private joys along their path are few'. Their ascetic and studious lives are structured to cultivate empathy for the common man and dedication to his liberation. It is a path that most men would not and could not follow, but that the few must pursue in the interests of all. See ibid., at 309-II, 320-I, 342-4. Lenin's own lifestyle and his concern to forge a core group of 'professional revolutionaries' reflect Chernyshevsky's influence.

68. '[T]he great revolutionary end spurns those base means and ways which set one part of the working class against other parts, or attempts to make the masses happy without their participation; or lower the faith of the masses in themselves and their organization, replacing it by worship for the "leaders".' Trotsky, supra note 62 , at 49 .

69. J. Dewey, 'Means and Ends' [1938], in Trotsky, Dewey and Novak, supra note 62, at 67, 7 I.

70. Ibid. 
generalizations be substantiated by detailed empirical observation. ${ }^{71}$ Accordingly, his apologism for the Communards' hostage killings rested on an assessment of the human stakes of the particular operation, not on the inevitability of human loss in the dialectical unfolding of history, let alone on the moral insignificance of individuals in the grand quest for utopia..$^{72}$ Moreover, the fact that Marx managed to find non-moral grounds for repudiating most instances of revolutionary terror, while not dispositive of his approach to circumstances where such grounds would be unavailable, suggests that at least he had no particular zeal for ruthless means. ${ }^{73}$ There is every reason to believe that Marx's views on ends and means accorded with those of Dewey, the liberal consequentialist, rather than with the sloppy formulations of Trotsky's 'Marxist-Leninist' polemic.

In sum, Marx's work embodies a normative stance that is fully compatible both with legal restraint on post-revolutionary rule and with the requisite concern for the incommensurable worth of human beings. To be sure, it is still possible to attribute to Marx some causal role in the atrocities committed in his name; his ideas nourished hopes for a dramatic liberation that could not be fulfilled in the manner expected, occasioning a 'demand', as it were, for a joining of Marxian critique and aspiration with heroic strategies drawn from revolutionary-populist traditions (Russian, Chinese, and other) - traditions, ironically, of the precise sort that Marx disparaged in unambiguous terms. But that causal link - not unlike the link between Rousseau and Robespierre, or between Jesus and Torquemada - in no way justifies dismissing the substantive content of Marx's actual work. With the removal of Marx from its 'enemies list', the human rights movement has every reason to examine whether Marxian thought might supply some distinctive contribution to its endeavour.

\section{Marx as Distinctive CONTRIbUtor to The human RightS PROJECT}

If Marxian thought neither disparages the human rights movement's normativetheoretical project nor espouses normative principles incompatible with that project, its affirmative contribution remains to be explored. Contemporary liberal

71. See, e.g., B. Leiter, 'Marxism and the Continuing Irrelevance of Normative Theory', (2002) 54 Stanford Law Review I I29, I I 42 (Marx's elaborations of the dialectical tendencies inherent in historical processes appear in the bulk of his work as 'simply a gloss on ordinary causal explanations'); Harrington, supra note 4I, at 54 (Marx rested his conclusions on empirical studies of capitalism's dynamics, not on his dialectical characterizations of those dynamics), $8 \mathrm{I}-2$ (Marx's insistence that connections suggested by theory be supported by empirical observation).

72. According to Marx, the Commune, to protect the lives of its own partisans taken hostage by the enemy,

was obliged to resort to the Prussian practice of securing hostages. The lives of the hostages had been forfeited over and over again by the continued shooting of prisoners on the part of the Versaillese. How could they be spared any longer after the carnage with which MacMahon's praetorians celebrated their entry into Paris? Was even the last check upon the unscrupulous ferocity of bourgeois governments - the taking of hostages - to be made a mere sham of? (Trotsky, supra note 62, at 39, quoting circular authored by Marx and issued by the General Council of the First International, available at http://csf.colorado.edu/psn/marx/Archive/I864-IWMA/I 87 I-CWF/cwfo3.htm)

73. See Avineri, supra note 29 , at I $87-8$. 
theory has moved well beyond the 'possessive individualism'74 that provided such an easy target for Marx's critique in On the Jewish Question. Its egalitarian variants (developed most prominently by John Rawls and Ronald Dworkin, but also importantly by Martha Nussbaum, Will Kymlicka, Jeremy Waldron, and many others $)^{75}$ have demonstrated the liberatory potential of liberal premises for a wide range of disempowered and deprived constituencies. Conversely, Marx, in fixating on the class dimension, provides little guidance to the social dynamics that produce systematic subordination and exclusion on bases such as race, ethnicity, gender, sexual orientation, and disability. Moreover, Marx's normative project presupposes not only exogenous developments (an ultimate crisis of capitalism that unifies the interests of the have-nots) that have failed to unfold, but also the establishment of material conditions (abundance superseding all conflict among genuine human needs) that appear beyond the realm of possibility. Why, then, do human rights advocates need Marx?

There is no reason to doubt that, I 20 years after Marx's death, there is much in the corpus of Marx's work that needs to be jettisoned, and that developments within the liberal tradition have generated substantial insights that a strictly Marxian framework does not supply or even accommodate. It would be misguided to assert a new 'Marxism' as a comprehensive replacement for 'bourgeois' approaches to political morality.

The discussion below nonetheless suggests two respects in which the Marxian inspiration continues to pose a worthy challenge to the main current of contemporary liberal approaches to human rights. The first concerns the implications of class divisions for the supposed universality of liberal rights. The second concerns liberalism's resistance to institutionalizing a privileged conception of human flourishing.

\section{I. Form and substance: beyond legality, rights, and democracy 'without adjectives'}

According to conventional wisdom, the eastern European experience has refuted the assertion, associated with Marxism, of a 'socialist legality', 'socialist rights', and a 'socialist democracy' that rival the 'bourgeois' variants. The rule of law, individual rights and democracy, properly so called, are said to exist, where at all, only 'without adjectives' ${ }^{76}$ This conventional wisdom reflects the altogether worthy rejection of an ends-oriented conception of legality, rights, and democracy that, in establishing the ruling clique as the authoritative interpreter of their defining ends, denuded these concepts of all practical content.

Nonetheless, the conventional wisdom's espousal of legality, rights, and democracy 'without adjectives' throws out the baby of Marxian insight with the bathwater of communist practice. Underlying this espousal is the claim that each of these concepts has an objective institutional content that stands above the ends that

\footnotetext{
74. See C. B. Macpherson, The Political Theory of Possessive Individualism: Hobbes to Locke (1962).

75. Representative works include: Rawls, supra note 52; R. Dworkin, Sovereign Virtue: The Theory and Prac tice of Equality (2000); M. C. Nussbaum, Women and Human Development: The Capabilities Approach (2000); W. Kymlicka, Liberalism, Community, and Culture (I989); J. Waldron, Liberal Rights (I993).

76. See Krygier, supra note I 5 , at 639 .
} 
competing normative tendencies might seek to accomplish through it. The clash of normative visions, it follows, properly occurs in an arena bounded by the 'basic structure' of a liberal society, a structure constituted by principles of legality, rights, and democracy that are neutral, internally coherent, and mutually reinforcing.

The Marxian contribution is to suggest that this neutrality and harmony of fundamental political values cannot be realized so long as a society's class antagonisms have not been transcended. Whereas liberalism's project is to devise a formula that renders the exercise of power rationally justifiable from the standpoint of every individual (qua distinct bearer of interests and values) subject to it, Marxism denies that such a formula is possible in a class-divided society.

The Marxian insight goes beyond the familiar observation that the differently situated realize differential benefits from liberal institutions. Liberals have long conceded that, in the words of Isaiah Berlin, 'to offer political rights, or safeguards against intervention by the state, to men who are half-naked, illiterate, underfed, and diseased is to mock their condition; they need medical help or education before they can understand, or make use of, an increase in their freedom'. ${ }^{77}$ Social-democratic liberals (often inspired by Marxian observations or under pressure from Marxist movements) have long advocated egalitarian socioeconomic reform to realize for all sectors of society the animating purpose of liberal norms: the furtherance of the individual's capacity for genuinely self-directed activity.

The difference is that whereas social-democratic liberals regard this struggle as the development of the liberal project to completion, Marxists see this struggle as laying bare contradictory interests and values of a class-divided society that are reflected as contradictions within the concepts at the core of the liberal mission. Thus, whereas a liberal can expect social change to be accomplished without doing any violence to legality, rights, and democracy as defined by prevailing conceptions and would evaluate a revolutionary regime's human rights performance on its continuing to uphold those conceptions - a Marxist anticipates that a crisis of the old order will force a choice between, as it were, 'their democracy and ours'.

Legality, rights, and democracy all trade on promises that, in a class-divided society, they must necessarily betray. In a capitalist society they will all naturally operate to reaffirm and reinforce the prevailing dynamics of economy and society, thus giving rise to a contradiction between the values they trade on and the effective conditions that the prevailing economic and social dynamics inflict on the subordinated classes. The class struggle will thus be played out as contestation over the essential meanings of these concepts.

\section{I.I. Legality}

The rule of law is illustrative. The concept is animated by a concern for predictability and accountability in the exercise of power, as these are necessary (though not sufficient) conditions for liberty and democracy respectively. Absent the secure knowledge that within fixed confines, however narrow, the individual can act on her

77. I. Berlin, 'Two Concepts of Liberty' [I958], in I. Berlin, Four Essays on Liberty ( I969), I I8, I 24. 
own free will without fear of reprisal, the individual has no possibility of pursuing her own life plan; she can protect herself (if at all) only by currying favour with those exercising power, and must forsake any agenda that might interfere with that imperative. Absent mechanisms effectively holding the exercise of governmental functions to fixed standards, the polity, however broadly and deeply participatory its processes, has no capacity to see to it that its decisions are faithfully executed.

These universal truths recommend a fundamental maxim of minimally tolerable governance: 'No power shall be exercised, but according to law.' Despite the manifest ambiguities of 'according to' (a spectrum of constraint on discretion leading all the way from 'as authorized by' to 'as dictated by') and 'law' (an ideal of fixity realized in actual statutes to widely varying extents), the maxim's defining purposes of predictability and accountability ensure at least a minimum of 'bite'. ${ }^{78}$ Accordingly, the Marxian historian E. P. Thompson, in a work that otherwise elaborately illustrated the 'shams and inequities' that lay 'concealed beneath' legal forms in early modern England, affirmed that 'the rule of law itself, the imposing of effective inhibitions upon power and the defence of the citizen from power's all-intrusive claims' is 'an unqualified human good'. ${ }^{79}$

Yet, in a class-divided society, the promises of legal protection from arbitrary imposition and of legal implementation of collective empowerment go largely unrealized. The rule of law, as conventionally conceived, ignores precisely those unpredictable and unaccountable exercises of power that most fully condition social life for those lacking command over resources: exercises of 'private' power. In a capitalist economy, decisions on matters of great human consequence (working conditions, firings, plant relocations, evictions, and so on) are decentralized. These decisions are typically attributed to 'the free market', a term that suggests a natural, non-political ordering process that operates independently of human will. Thus standards appropriate to the exercise of public power are made to appear inapplicable. Nonetheless, actual private decisions over the conditions of others' lives are often highly discretionary (sometimes even whimsical), and these decisions, far from being genuinely outside the state realm, are governmentally recognized, facilitated, and enforced. Moreover, the notion of 'the free market' (which in its best usage presupposes conditions such as free and equal access to market information, low barriers to market entry and an inability of enterprises to 'externalize' their costs) tends to be invoked irrespective of concentrations of market power within the private sector, and even of direct and indirect governmental subsidies in aid of those concentrations. ${ }^{80}$

78. One of the greatest exponents of the rule of law, Lon Fuller, attributed to law an 'internal morality' entailing a set of formal qualities (i.e., that enactments be general, public, non-retroactive, clear, not in contradiction of one another, susceptible of compliance, stable, and enforced according to their terms) that are supposed to be 'neutral toward substantive aims'. L. L. Fuller, The Morality of Law (I969), 46-9I, I53. Fuller recognized, however, that these qualities are realized in practice only to a greater or lesser extent, and that the internal morality is a matter of overall fulfilment of essential purposes ascribable to law. '[T] here would', for example, 'be a certain occult unpersuasiveness in any assertion that retroactivity violates the very nature of law itself.' Fuller, 'Positivism and Fidelity to Law: A Reply to Professor Hart', (I958) 7 I Harvard Law Review 630, 650.

79. Thompson, supra note 18 , at 266.

80. Marx, whose study of capitalism included a discourse on 'commodity fetishism', K. Marx, Capital, Vol. $I$, in MER, supra note II, at 3I 9-29 (the 'ultimate money-form of the world of commodities ... conceals, instead of disclosing, the social character of private labour, and the social relations between the individual producers'), 
Thus the substantive values at the core of the rule of law - protection from arbitrary deprivation of conditions essential to one's life plans, and the capacity to bring the decisions that affect one's life under some measure of collective control are values systematically under-realized for the subordinate class in a capitalist society. Since this situation can be remedied only by the progressive imposition of popular will on the defining activities of the capitalist class, thereby largely reversing the roles, the result is in some measure a zero-sum game. It is no accident that pro-capitalist ideology often invokes rule-of-law considerations, not implausibly, precisely to block the extension of legal guarantees and popular control to the operation of private enterprise. ${ }^{81}$ Consequently, one's class perspective may reasonably determine whether one deems a given measure to further or to erode the rule of law.

The point comes into starker relief in the 'public' realm when class and ideological conflict strain constitutional arrangements to breaking-point. Given the inherent woolliness of the demand that governmental power be exercised only 'according to law', the stakes of a situation tend to determine how much discretionary power is thought to be compatible with the rule of law. Crises typically occasion an increase in discretionary authority, whether through the adoption of broad legislative authorizations or through the invocation of emergency powers. The authorization of such measures is typically justified, on the ground that 'the Constitution is not a suicide pact', in terms that lay bare the substantive values that the constitutional structure supposedly exists to defend. ${ }^{82}$ What is then exposed is that the constitutional propriety of such exercises of power turns principally on 'to whom' the Constitution ultimately belongs. As Carl Schmitt noted, 'Public order and security manifest themselves very differently in reality, depending on whether a militaristic bureaucracy, a self-governing body controlled by the spirit of commercialism, or a radical party organization decides when there is order and security and when it is threatened or disturbed. ${ }^{83}$

The Marxian insight is that the contradictions of a class-divided society are manifested as inherent tensions and indeterminacies within core liberal values. Extremists have appropriated this insight for the crude claim that the rule of law in bourgeois society is nothing more than a sham, and the still cruder claim that the problem to which the concept responds is overcome once the reins of power are seized by a revolutionary party representing the objective interests of the subordinated class. Neither of these claims follows from the Marxian premise. Not only

would surely be amused by today's tendency to fetishize market relations. The free-market rhetoric goes beyond likening market forces to forces of 'nature' in the physical sense, since science and technology operate to free human beings from natural limitations (such as the inability to fly); instead, the 'nature' metaphor seems to be a teleological one, an appeal to a morally ordered universe analogous to the appeal that underlies the claim that homosexuality is 'unnatural'.

8I. Illustrative is F. A. Hayek, The Constitution of Liberty (I960), I48-6I. On the other hand, the same concerns about impositions of will can be adapted to justify casting redistribution of essential resources to the poor as a matter of unconditional right. See C. Reich, 'The New Property', (I964) 73 Yale Law Journal 733.

82. Compare G. H. Fox and G. Nolte, 'Intolerant Democracies', (I995) 35 Harvard International Law Journal $\mathrm{I}$, with M. Koskenniemi, B. R. Roth, G. H. Fox and G. Nolte, 'Responses', (I996) 36 Harvard International Law Journal 37 (debating the democratic merit of repressive measures against anti-democratic parties), reprinted as adapted in G. H. Fox and B. R. Roth (eds.), Democratic Governance and International Law (2000), 389-448.

83. Schmitt, supra note 44 , at $9-$ IO. 
did Marx acknowledge the legal forms of the bourgeois revolution to represent a genuine (if incomplete) emancipation, but he acknowledged these forms as genuine (if incomplete) responses to the social reality of domination and compulsion, to be overcome only when societal development transcends the oppositions that underlie all subjection of one human being to the will of others. A capitalist-oriented rule of law must, in the first instance, be supplanted by a socialist-oriented rule of law, itself animated by the imperatives of predictability and accountability in the exercise of power, in ways that maximize their relevance to the real lives of the broadest sectors of society.

Still, to speak of a rule of law 'without adjectives' is to neglect the essential partisanship with which any conception of the rule of law must, consciously or unconsciously, be suffused. Such neglect lays the groundwork for a 'neutral' human rights scrutiny that will be systematically skewed against movements for radical social change operating outside the bounds of 'lawful' authority, and against revolutionary regimes seeking to restructure economic and social institutions over the entrenched opposition of privileged sectors. An approach informed by the Marxian insight will not rationalize whatever thuggery announces revolutionary pretensions, but at the same time will not misidentify as mere thuggery revolutionary activity that seeks to revise the terms of class relations.

\subsubsection{Rights}

The same analysis applies, mutadis mutandis, to the substance of rights. Traditional negative rights, such as those at the core of the International Covenant on Civil and Political Rights, have differential worth to those occupying privileged and subordinate positions, respectively, within economic and social institutions. Socialdemocratic liberals appreciate the truth underlying Anatole France's tart observation that ' $[t]$ he law in its majesty draws no distinction, but forbids rich and poor alike from begging in the streets or sleeping in public parks. ${ }^{84}$ What is less widely appreciated is that the right to free expression protects soap-box ranters and media moguls alike in their efforts to affect social consciousness, whether to problematize or to normalize the subordination and exclusion of the disempowered.

Much of the freedom that negative rights protect amounts to a freedom to exercise power: at best, power over the conditions of one's own life and a proportionate share of power in collective processes of decision-making over the shared conditions of social life; at worst, a disproportionate share of power over the conditions of others' lives. Indeed, where this disproportionate power is exercised directly, as in the exclusion of racial minorities from privately owned public accommodations, liberals have come to acknowledge it and to advocate restrictions on it in the name of liberal freedom.

The economic and social power of a dominant class typically manifests itself less directly, but no less weightily. As Lukes has pointed out in his classic work on the 'three dimensions' of power, elites frequently possess the capacity not merely to win

84. H. Zinn, 'The Conspiracy of Law', in R. P. Wolff (ed.), The Rule of Law (I97 I), I 5, 32. 
such political conflicts as arise, or merely even to frame the issues that arise, but further to dissuade the underprivileged from understanding their life difficulties as bases for political demands. ${ }^{85}$ In particular, society's dominant forces act - in a mostly spontaneous but nonetheless structured fashion - to maintain and deepen a consumer-oriented culture, thereby impeding both the recognition of class interests and the development of habits of collective action. Cultural hegemony operates to sustain domination behind the mask of a formal regime of freedom and equality.

More concretely, rights can function as shields behind which privileged elites, when confronted by governments bent on economic and social reform or transformation, can act to mobilize resistance and to generate economic chaos. As illustrated in the history of populist and socialist governments in the western hemisphere (e.g., Guatemala in the early I950s, Chile in the early I970s, Jamaica in the late I970s, Nicaragua in the I980s, and Venezuela today), the struggle to implement structural change in stratified societies can culminate in political crises that raise serious questions about whether protection of the destabilizing oppositional activities of entrenched elites serves or disserves the liberatory goals of the human rights movement.

This Marxian line of critique suffers from a bad reputation, owing to the crudity and one-sidedness of many of its former applications. Part of the problem is fairly attributed to errors in Marx's own thinking. As noted above, Marx wrongly expected, on the one hand, a progressive unification of both the economic interests and the political consciousness of those diverse sectors lacking command over the major means of production, and on the other hand, a progressive sharpening of capitalism's economic contradictions that would impel the unified have-nots to a root-andbranch rejection of the status quo. These predictions gave rise to an oversimplified understanding of the political aspects of economic conflict. In reality, different sectors of the have-nots are differently situated; the political task is not merely to reveal the inherent harmony of their economic needs, but affirmatively to develop a programme that reconciles them. Class interests are not so much 'objective' as subject to conflicting reasonable interpretations. The political choice is at all times not between intolerable economic conditions and a great leap into the dark, but between better and worse projected outcomes, which in turn can be gauged only according to competing normative understandings of what mixes and distributions of improvements and detriments count as just and beneficial.

An oversimplified understanding of what is at stake in political conflict has frequently led self-styled continuators of the Marxian tradition to a number of poorly reasoned conclusions about rights. These have ranged across a spectrum of embarrassments, from a simplistic inversion of the typical liberal-democratic prioritization of civil and political over economic and social rights, to the notion that socialist civil and political rights properly exist 'in order to strengthen and develop the socialist system', and therefore are exercisable only 'in accordance with the aims of building communism', as these aims are authoritatively interpreted by the revolutionary

85. S. Lukes, Power: A Radical View (1974), 24. 
leadership. ${ }^{86}$ As noted above, whereas Luxemburg's interpretation of Marx properly understood socialism as the set of policies that the working people themselves choose - by collective decisions derived from the autonomous participation of each, in a process open to the expression of the widest range of disagreement - the communists came remarkably close to defining the working people, the bearers of 'socialist rights', as the supporters of objectively progressive policies. By this logic, the rights of individuals are reducible to the right to play out a scripted role in a revealed historical drama. The incompatibility of any such notion with the human rights project is self-evident.

Notwithstanding these catastrophic mistakes of supposed Marxists, the essential Marxian insight remains unrefuted. Socioeconomic stratification, in rendering rights-bearers differently situated to a radical extent, renders the universal application of traditional liberal rights not only insufficient for the realization of universal liberal values, but also, at least potentially in some circumstances, detrimental to efforts to effect that realization for subordinated classes. The overcoming of class divisions is a necessary (whether or not sufficient) condition for dissolving the clashes within the liberal scheme of values, which otherwise need to be addressed case-bycase in a non-dogmatic effort to further the overall conditions of a dignified human existence.

\subsubsection{Democracy}

The shortcomings of 'democracy without adjectives' are still easier to demonstrate. Empirically oriented political scientists conventionally identify democracy with a set of institutional requisites: fair electoral processes, freedom to organize competing parties, an uncensored press, and so on. ${ }^{87}$ This institutional definition is designed to abstract from potentially contentious questions about the institutions' relationship to a presumed source of political authority (e.g., 'popular will') or to the ends with which democracy might be associated (e.g., equality of power over the conditions of social life). ${ }^{88}$

This same non-teleological approach to defining the phenomenon has recently been adapted to the normative claim for a right to democracy. ${ }^{89}$ But whereas it is at least coherent (whether or not persuasive) to speak of fulfilment of other rights

86. The quoted words are from Arts. 50 and $5 \mathrm{I}$ of the 1977 Soviet Constitution.

87. The requisites typically cited track Robert Dahl's seven criteria of 'polyarchy'-essentially, constitutional rule based on fair elections, combined with freedom of expression and of association. See R. A. Dah1, Democracy and Its Critics ( 1989 ), 233.

88. The contemporary comparative politics literature justifies rejecting teleological definitions of democracy on the ground that these render democratic performance inherently unmeasurable by social science techniques. This justification is understood by social scientists to entail lightening the term's normative baggage that is, identifying democracy as, at most, one of many political virtues. See S. Huntington, The Third Wave: Democratization in the Late Twentieth Century (I99I), 5-13. Advocates of a human right to democratic governance' have nonetheless imported, rather dubiously, this simplification from the empirical into the normative realm.

89. See T. M. Franck, 'The Emerging Right to Democratic Governance', (I992) 86 AJIL 46; G. H. Fox, 'The Right to Political Participation in International Law', ( I992) I7 Yale Journal of International Law 539. For an overview of the issues raised by the claim, see G. H. Fox and B. R. Roth, 'Democracy and International Law', (200I) 27 Review of International Studies 327. For critical accounts of the 'democratic entitlement' claim, see B. R. Roth, Governmental Illegitimacy in International Law (I999); S. Marks, The Riddle of All Constitutions: International Law, Democracy, and the Critique of Ideology (2000). For a sampling of competing evaluations, see Fox and Roth, supra note 82. 
as representing an imperative independent of the purposes for which an individual right-bearer might choose to exercise it, the same cannot be said for a right to democracy. No one values democracy for mere joy of going into a voting booth every few years to choose among different lists of candidates. (Even civic republicans, who regard the activity of political participation as end in itself, have in mind a much different conception of what that activity encompasses.) A right to democracy can be rooted only in the value of a democratic social reality that institutions are calculated to bring about, and so cannot ultimately be defined in abstraction from its animating purposes. ${ }^{90}$

Competing normative theories, however, assign to democracy differing, and often conflicting, animating purposes. The prevailing view, which the anti-Rousseauian Benjamin Constant articulated with great clarity almost two centuries ago, is that democracy aims to effect individual freedom, no longer in the sense of equal and direct participation in the decisions of a social whole ('the liberty of the ancients'), but in the sense of making society safe for the pursuit of diverse private interests ('the liberty of the moderns'). ${ }^{\text {1 }}$

In the long term, the Marxian hope is to overcome this dichotomy through a thoroughgoing transformation of economic relations. The liberty of the ancients, which Rousseau hoped could still be realized in the modern world, envisages a 'general will', arising from participatory processes, that holistically reconciles the freedom of each with the freedom of all. Rousseau understood that any such vision presupposes the overcoming of power disparities among classes, so that no citizen is 'wealthy enough to buy another, and none poor enough to be forced to sell himself'. ${ }^{2}$ His intensive conception of 'generality' required that citizens be so similarly situated that the benefits and burdens of public acts would fall equally across the citizenry, leading each to identify his own interests with the interests of the whole. ${ }^{93}$ In such circumstances, participation in common projects and enjoyment of public goods were expected to furnish a greater part of individual happiness, leaving less need to seek fulfilment through the furtherance of private interests. ${ }^{94}$

90. See B. R. Roth, 'Evaluating Democratic Progress: A Normative Theoretical Perspective’, (I995) 9 Ethics and International Affairs 55, reprinted in Fox and Roth, supra note 82, at 493; Roth, 'Democratic Intolerance: Observations on Fox and Nolte', (I996) 37 Harvard International Law Journal 235, repr. in Fox and Roth, supra note 82, at 44I. For a remarkably ends-oriented account of liberal democracy, disparaging the conventional emphasis on electoral participation, see R. A. Dworkin, 'The Moral Reading and the Majoritarian Premise', in H. Hongju Koh and R. C. Slye (eds.), Deliberative Democracy and Human Rights (I999), 8 I.

9I. B. Constant, 'The Liberty of the Ancients Compared with that of the Moderns', in Benjamin Constant: Political Writings, trans. B. Fontana (1988), 307-28.

92. J.-J. Rousseau, 'The Social Contract', in Rousseau, The Social Contract and Discourses, trans. G. D. H. Cole (I973), I63, 204 (bk. II, ch. II).

93. In J.-J. Rousseau's conception, 'every authentic act of the general will binds or favors all citizens equally; so that the Sovereign recognizes only the body of the nation, and draws no distinctions between those of whom it is made up... The Sovereign never has a right to lay more charges on one subject than on another, because, in that case, the question becomes particular, and ceases to be within its competency.' Rousseau, supra note 92, at I63, I 88 (bk. II, ch. 4) (emphasis added). Since 'all continually will the happiness of each one', and every citizen considers 'each' to mean himself, every citizen will vote for the good of the whole in consideration of his own good. Ibid., at I 86-87 (bk. II, ch. 4).

94. Ibid., at 240 (bk. III, ch. I5). The functioning of the general will does not require, however, that individuals no longer differ in their interests and values. "If there were no different interests, the common interest would be barely felt, as it would encounter no obstacle; all would go on of its own accord, and politics would cease to be an art'. Ibid., I85, n. I (bk. I, ch. 9). Rousseau and Marx are harmonized by Will Kymlicka's astute observation that Marx's vision of end-stage communism entails the overcoming only of class antagonisms, 
But, as Marx recognized, past efforts to reconcile 'citizen' (participant in political community) with 'man'(pursuer of private interests) had either lacked the economic requisites for the identification of the freedom of one with the freedom of all (thereby reducing to 'utopianism') or had been predicated on the assignment of productive labour to a large class of non-citizens (i.e., slavery in the ancient world). With the transcendence of scarcity, of the capitalistic division of labour, and therefore of external control over the individual's productive powers, Marx envisaged finally transforming a circumstance in which 'species-life itself - society - appears as a system which is external to the individual and as a limitation of his original independence' into one in which 'the real, individual man has absorbed into himself the abstract citizen', and the 'individual man, in his everyday life, in his work, and in his relationships, ... has become a species-being. ${ }^{95}$ Lucio Colletti summarizes the point, if perhaps exaggeratedly, in his assertion that 'revolutionary "political" theory, as it has developed since Rousseau, is already foreshadowed and contained in The Social Contract', and that Marx and Lenin have added nothing, 'except for the analysis ... of the "economic bases" for the withering away of the state'. ${ }^{6}$

Marx's immediate relevance, however, is to the shorter term, where the prevailing concern must remain a genuine extension of 'the freedom of the moderns' to the subordinated class. The Marxian observation here is that those sectors of society having real weight in political decision-making tend to win the conditions of freedom relevant to those sectors. The primary condition of freedom for those with command over resources is the protection of the individual from state encroachment, whereas the primary condition of freedom for the have-nots is an end to economic deprivation and insecurity and to social disempowerment and exclusion.

Although the right to democracy trades heavily on the ideal of political equality, what passes for democracy in the prevalent discourse is an institutional structure that both reflects and works to stabilize power disparities in the 'private' realm. While attention is focused on each citizen's free exercise of a single vote, 'insiders' determine the composition of candidate lists, candidates are beholden to campaign contributors, mass media outlets frame the political issues, and large commercial interests have macroeconomic leverage over local elected officials. ${ }^{97}$

The more rigid the social stratification and the more widespread the economic deprivation, the more frequently has formal political equality been perceived to

not of conflicting individual goals and projects. Kymlicka, supra note 75, at I I 8-I9. Notwithstanding Marx's reservation of the word 'political' for modes of governance that entail class domination, it appears that end-stage communism's residual co-ordination authority was intended to embody a realization of the Rousseauian scheme.

95. Marx, supra note 34 , at 3 I.

96. L. Colletti, From Rousseau to Lenin: Studies in Ideology and Society, trans. J. Merrington and J. White (I972), I85.

97. Susan Marks exposes the prevailing vision of democratization as both shallow and narrow: shallow in that it identifies the democratic norm with a 'low-intensity democracy' that emphasizes electoral competition among elites at the expense of mass participation and empowerment; narrow in that it aims at democracy within the boundaries of each state - 'pan-national democracy' - without concern for democratic control of those realms of decision-making that are increasingly transnational. Marks, supra note 89, at 50-Ioo. In her view, assertions of an international democratic norm give an imprimatur to procedural reforms that are intended less as an opening to the thoroughgoing transformation of decision-making processes that govern economic and social life than as a strategy for deflecting pressures for such transformation. 
mock the moral authority associated with the word 'democracy'. Especially in underdeveloped countries, where these conditions are endemic, liberal-democratic procedures typically do little to enhance the power of the poor majority to influence the social decisions that affect their lives. The capacity to select periodically from among pre-packaged candidates of elite-controlled parties scarcely implies the rudiments of accountability, let alone genuine popular empowerment. Popular prerogative to reject one given set of administrators of the social order in favour of another, while not a trivial development, is very far from the power to make government responsive to popular initiatives, input or needs. Where opposition groups operate without resources in a context of widespread illiteracy, economic dependence, and entrenched habits of deference to traditional authority, meagre are the prospects for making real the promises associated with the democratic label.

A Marxian approach would posit as the essence of democracy the effective equality of power in social decision-making. An appropriate measure of democracy, then, is the extent to which the interests and views of the bottom half of the socioeconomic ladder have commensurate weight in political decision-making - a consideration notably absent in the literature on the right to democracy. On this view, fidelity to familiar electoral procedures should be subject to the overarching purpose of substantive social empowerment of the resource-deprived.

Accordingly, militant opposition to fairly elected governments, including tactics exceeding the bounds of legality, cannot be sweepingly dismissed as inimical to genuine democracy. Moreover, one cannot rule out a priori that authoritarian and coercive practices calculated to break the effective hold of socioeconomic elites may, under certain conditions, be a more democratic alternative to 'free and fair elections' that, for structural reasons, systematically ratify the status quo.

This is not to say that a posteriori examination will frequently vindicate such measures, the historical consequences of which have tended to be setbacks to popular empowerment. It is also not to deny that liberal-democratic procedural mechanisms can constitute a real achievement that creates crucial space for agitation in favour of subordinated sectors of society - an achievement that Marx himself indisputably valued.

A Marxian orientation does, however, expect that in class-divided societies, internal tensions and contradictions will inevitably mark the application of the concepts of legality, rights, and democracy, in striking contrast to the more conventional image of a seamless web of mutually reinforcing values. This insight qualifies as a substantial contribution to the intellectual infrastructure of the human rights project.

\subsection{Socialist ends: beyond the right-good distinction}

The second Marxian contribution to normative human rights theory is to call into question the 'neutralist' ethos predominant in contemporary liberal thought. Marx attributed to human beings an innate potential for creative self-expression that achieves realization only in unalienated social labour. To achieve genuine human emancipation, the oppressed class must take collective action to forge new economic and social arrangements that will not only marshal economic resources to meet 
needs on an equal basis, but will also transform work into the vehicle for the fulfilment of creative powers. That process is envisaged progressively to overcome the egoistic opposition of individuals one to another, thereby bringing about 'the return of man to himself as a social, i.e., human, being..$^{8}$ The project of social transformation presupposes a 'truly human' way of life to be pursued collectively (albeit one that exalts individual self-direction within the designated parameters), in contrast to a debased one under capitalism pursued by individuals in isolation.

Conversely, deontological liberalism rejects all political manifestations of 'perfectionism' - efforts to further, through compulsory collective decisions, a determinate conception of the good life -insisting instead on an equality of human beings qua individual end-choosers. Thus Martha Nussbaum characteristically seeks to limit the political project to the furtherance of 'central human capabilities', as opposed to the furtherance of any particular model of 'human functioning'. While acknowledging that Aristotle and Marx, her sources of inspiration, can be invoked for both projects, she asserts that 'there is a big difference between pushing people into functioning in ways you consider valuable and leaving the choice up to them'. ${ }^{99}$

If, however, 'capabilities' and 'functioning' are interdependent, the deontological wall of separation between 'the right' (moral judgements about fairness to human subjects) and 'the good' (moral judgements about the proper objects of human striving) cannot be sustained. Putting aside the debater's point that the distinction itself may be nothing more than a sleight-of-hand - proper functioning may effectively be the ultimate test of the true realization of capabilities - interdependence is established if proper functioning is indispensable to the social conditions needed for capabilities to be developed. In refusing to take compulsory collective decisions that presuppose and reinforce the common pursuit of a new way of functioning, a society governed by neutralist liberalism may systematically neglect to produce the public goods (both tangible and intangible) that form the structural basis for development of new capabilities. If that proves to be the case, it would follow that deontological liberalism serves, in the guise of neutrality on the proper mode of 'human functioning', effectively to reaffirm and to reinforce an existing way of life that actually stunts the development of certain 'central human capabilities'.

The issue is not limited to abstractions or to projected policies for a remote future society, but rather pertains to concrete, present-day social-democratic practice. The neutralist approach, although favouring redistribution to reduce inequality among individual end-choosers, embraces markets as non-coercive instruments of co-ordination, not solely for the sake of efficiency, but for the sake of neutrally empowering individual choice. In contrast, a social democratic perfectionism may pursue not merely a Rawlsian distributive justice (allowing only such inequalities as improve the conditions of the worst off), ${ }^{100}$ but also societal goals derived from a peculiarly socialistic conception of the good life: for example, relative equality

98. Marx, supra note 26, at 84 .

99. Nussbaum, supra note 75 , IOI.

I00. For an elaboration of the 'difference principle' as the basis for distributive justice, see Rawls, supra note 75 , supra note 52 , at $75-83$. 
per se (even where greater inequalities might increase somewhat the incomes of the poor); an ethos of frugality; broad and deep popular participation in collective projects; workers' control over the workplace environment; security against risks to basic material needs; and stability of the economic bases of local communities. Absent a collective decision, market-based aggregations of individual choices would tend, for structural reasons, to drive out these socialistic goals in favour of more individualistic ends. The collective non-decision, while purportedly neutral, would facilitate some modes of human 'functioning' while undermining others.

Genuine freedom, Marx insisted,

can only consist in socialized man, the associated producers, rationally regulating their interchange with Nature, bringing it under their common control, instead of being ruled by it as by the blind forces of Nature; and achieving this with the least expenditure of energy and under conditions most favourable to, and worthy of, their human nature. ${ }^{\text {IOI }}$

According to Marx's early work on alienation, man is distinguished from lower animals in that he 'makes his life-activity itself the object of his will and of his consciousness'. ${ }^{102}$ 'Activity and consumption are social in their content as well as in their mode of existence; they are social activity and social consumption'. ${ }^{103}$ Thus, even

when I am active scientifically, etc., when I am engaged in activity which I can seldom perform in direct community with others - then I am social, because I am active as a man. Not only is the material of my activity given to me as a social product (as is even the language in which the thinker is active): my own existence is social activity, and therefore that which I make of myself, I make of myself for society and with the consciousness of myself as a social being. ${ }^{\mathrm{IO}}$

Social production, so understood, is humanity's life activity, the expression of human creativity and the prime need of a genuinely human existence; only through an organization of productive activity that estranges man from his essential nature does he come to regard productive activity only as a means of life.

Marx observed that under the capitalist mode of production, which 'throws back some of the workers into a barbarous type of labour and turns the others into machines', man

in his work ... does not affirm himself but denies himself, does not feel content but unhappy, does not develop freely his mental and physical energy but mortifies his body and ruins his mind .... As a result, therefore, man (the worker) no longer feels himself to be freely active in any but his animal functions - eating, drinking and procreating, or at most in his dwelling and in dressing-up, etc.; and in his human functions he no longer feels himself to be anything but an animal. What is animal becomes human and what is human becomes animal. ${ }^{105}$

As a result, the individual's need to express himself through co-operative and socially useful productive activity is lost from consciousness, replaced by egoistic needs of the 
individual as consumer that capitalist processes systematically multiply to further the accumulation of capital.

[E]very person speculates upon creating a new need in another, so as to drive him to a fresh sacrifice, to place him in a new dependence and to seduce him into a new mode of gratification and therefore economic ruin. Each tries to establish over the other an alien power, so as thereby to find the satisfaction of his own selfish need. ${ }^{\text {I06 }}$

Under capitalism, the supremacy of egoistic (pseudo-)needs assures that human beings are pitted against one another. Every man comes 'to see in other men, not the realization, but rather the limitation of his own liberty'. ${ }^{107}$

But under socialism, this ceases to be so: 'we shall have an association, in which the free development of each is the condition for the free development of all'. ${ }^{\text {I08 }}$ The fulfilment of necessity, says Volume III of Capital, permits 'that development of human energy which is an end in itself, the true realm of freedom', the 'basic prerequisite' of which is 'the shortening of the working day'. ${ }^{\text {Iog }}$ According to Volume IV (a work otherwise known as Theories of Surplus Value):

[F]ree time, disposable time, is wealth itself, partly for the enjoyment of the project, partly for the free activity which - unlike labour - is not dominated by the pressure of an extraneous purpose which must be fulfilled, and the fulfilment of which is [instead] regarded as a natural necessity or a social duty, according to one's inclinations. ${ }^{\text {Ito }}$

It follows that the shortening of the working day has an objective priority over the pursuit of superfluous - that is to say, low-pleasure-oriented and statusoriented - consumption, a pursuit that enlarges the realm of necessity and thereby increases the subjection of human labour to an alien power. A socialist society will, in bringing economic forces under rational control, have a collective interest in suppressing rampant consumerism and competitive quests for 'positional' goods. ${ }^{\text {I I }}$ Establishing the conditions of genuine human freedom requires establishing conditions conducive to the development of a consciousness of human beings' true nature and true needs - in other words, collective decisions presupposing a perfectionist commitment to a particular conception of the proper objects of human striving.

The dominant strain of contemporary social-democratic liberalism holds compulsory collective decisions to be admissible in aid of the production of 'neutral' public goods that furnish appropriate conditions for individual choice, but are inadmissible where they presuppose a controversial conception of the good. ${ }^{12}$

\footnotetext{
106. Ibid., at 93 .

107. Marx, supra note 34, at 26, 42.

I08. K. Marx and F. Engels, 'The Manifesto of the Communist Party' [I848], in MER, supra note II, at 469, 49 I.

IO9. MER, supra note II, at 44I.

I IO. K. Marx, Theories of Surplus Value (I962), III, 257, quoted in Lukes, supra note 47, at 207.

III. The significance of a 'positional' good lies in the social status one gains by possessing it while others do not, or, more importantly, in the social status or access one loses by not possessing it while others do. A typical characteristic of positional goods is that most people would be better off if all entered into a binding agreement not to pursue them. See R. H. Frank, Choosing the Right Pond: Human Behavior and the Quest for Status (I985).

II2. Elizabeth Anderson asserts that 'the capabilities citizens need to function as equals in civil society count as neutral goods for purposes of justice not because everyone finds these capabilities equally valuable, but. because reasonable people can recognize that these form a legitimate basis for making moral claims on one another'. E. S. Anderson, 'What is the Point of Equality?', (I999) Iog Ethics 287, at 330. Note, however, that
} 
Conversely, a social democratic perfectionism, though not seeking directly to impose one ideal way of life, is partisan among visions of the good life, and it attempts actively to effect the social requisites to lives it recognizes as good.

These requisites are achievable only through a distinctively collective, rather than individual, mode of rationality. Without the assurance that their sacrifices lock others into a scheme of co-operation, individuals have no incentive to forgo an individual benefit for the sake of contribution to a public good. The logic of market rationality leads to the pursuit only of those goods that can be secured by one's own independent activity. Where all decisions that reflect a distinctive conception of the good life are left to individual choices, co-ordinated by market mechanisms, the public goods conducive to co-operative development are systematically neglected.

To abjure 'non-neutral' collective decisions is thus to impose by default a determinate collective view of what individuals ought to be free to do. Teleology, turned away at the front door, comes in through the back. And the telos is an atomistic one, not by design, but by default.

The essential Marxian insight, then, is that liberalism's pretensions to neutrality, even in the highly nuanced form expounded by egalitarian liberals, mask its deep structural affinity for prevailing patterns of human functioning that reflect and reinforce existing hierarchies. This insight is applicable to the struggles to overcome social dynamics that produce systematic subordination and exclusion on bases other than those on which Marx focused, such as race, ethnicity, gender, sexual orientation, and disability. ${ }^{113}$

Still more broadly, a Marxian sensibility is on guard against flawed arguments from neutrality that liberals typically invoke against tyrannical perfectionisms. Instead of unpersuasively dismissing conservatives' identification of meaningful freedom with embeddedness in a supportive social environment, sustained by a shared commitment to certain of what Wilmoore Kendall termed 'public truths' (i.e., 'standards upon whose validity a society is entitled to insist'), ${ }^{\text {II }}$ human rights advocates will do better to take issue with the conservatives' 'public truths' on their merits. The Marxian inspiration contributes to a competing affirmative vision, thus providing a further resource to the human rights project.

\section{Conclusion}

The foregoing essay has sought to vindicate three propositions. First, Marxian thought contains an ample normative component that withstands the failure of Marxian predictions about economic history. Second, the Marxian approaches to the instrumentalities of revolutionary rule and to revolutionary morality, while reflecting an unflinching and unsentimental resolve, entail no general rejection of human rights-oriented constraint, procedural or substantive, on the exercise of

this statement assumes it to be possible to make a 'neutral' assessment of 'what capabilities citizens need to function as equals in civil society'.

I I 3. For my effort to apply a parallel analysis to the liberation of women, see B. R. Roth, "The CEDAW as a Collective Approach to Women's Rights', (2002) 24 Michigan Journal of International Law I 87.

I I 4. W. Kendall, “The "Open Society” and Its Fallacies', (I 960) 54 American Political Science Review 972, 974. 
power in the name of the revolution. Third, a Marxian orientation contributes to the human rights project normative insights not supplied by, and in some respects at odds with, the main current of contemporary liberalism. Marxism retains its relevance in the current period, not as a comprehensive replacement for liberal human rights theories, but as a source of critique that challenges those theories on the basis of the very values of human freedom and dignity that they espouse, and as a source of alternative gauges of whether particular policies advance those values.

The theme of the Marxian critique is that, in a class-divided society, liberal institutions not only systematically fail to realize for all sectors the values on which they trade, but also tend, by virtue of their formal neutrality, to reaffirm and reinforce the structural dynamics of economy and society that maintain the disempowerment of subordinated sectors. Liberal theory normalizes the indignities associated with the operation and maintenance of the prevailing order, while identifying as exceptional the harsh responses occasioned by that very order's contradictions. The contradictory interests and values of a class-divided society are thus reflected as contradictions within the core of the liberal mission. Whereas liberalism purports to represent a set of harmonious and mutually reinforcing values, a Marxian analysis reveals internal tensions that cannot be overcome until class antagonisms are themselves transcended. The class struggle is thus played out as contestation over the essential meanings of the normative concepts to which liberalism appeals.

Viewed in this light, the human rights movement's conventional rhetoric often appears as question-begging, and its prescriptions as one-sided and lacking in nuance. At the same time, a Marxian approach recommends no sweeping rejection of liberal values and practices, and in the greatest number of real-world instances reaffirms the liberal human rights mission, albeit on a somewhat different rationale. Marx further provides inspiration to an affirmative project of social democratic perfectionism, a political morality that extends beyond the limits of a 'neutral' distributive justice to demand the establishment, through collective decision, of economic and social conditions conducive to 'genuinely human' modes of functioning.

The twentieth century saw the refutation of a series of political experiments that invoked a Marxian aim of egalitarian social transformation. Nonetheless, the refutation of these experiments - all of which occurred in circumstances that Marx never foresaw and resorted to devices that Marx never recommended-does not invalidate the insights that prompted so many to embrace these experiments, often allowing their hopes to get the better of their reason. While no one should romanticize or seek to revisit these experiments, neither should one consign to the dustbin the ideas that inspired generations of activists to take up the cause of fundamental social change. There is much in those ideas that can be retrieved for the contemporary human rights project and contribute to the enduring aim of securing the conditions of a dignified human existence for all. 